\title{
CURRENT DEBATES IN THE POST- SOEHARTO INDONESIAN ISLAM: Examining the Intellectual Base of Liberal and Anti-liberal Islamic Movement
}

\author{
Akh. Muzakki \\ State Institute for Islamic Studies (LAIN) Sunan Ampel Surabaya, Indonesia; \\ PhD student at the School of History, Philosopby, Religion and Classics \\ (HPRC), the University of Queensland, Australia
}

\section{Abstract}

This article discusses intensively the current debate between those who support and against liberalism within pluralized Indonesian Muslims. The two groups are represented by JIL (Jaringan Islam Liberal) and MD (Media Dakwah). The author compares three fundamental aspects of religious interpretations: epistemological assumptions, methodological framework, and subject-matter. Epistemological assumptions deal with philosophical foundations that are employed by JIL and MD as principles to understand Islam. Methodological framework means the way the two groups understand and interpret Islam and its teaching based on their philosophical foundations. In terms of subject-matter, the author discusses six issues, namely (1) ijtihad; (2) approaches to text; (3) the meaning of truth; (4) the minority and the oppressed; (5) freedom of religion; and (6) mundane and spiritual authority. From the three fundamental aspects of religious interpretations that are compared, the author concludes that JIL is a group of Muslims who understand Islam by implementing liberalism, while MD (DDII) represents a group of Muslim who promote conservatism, purification, and anti-liberalism within Indonesian Islam.

Keyword: pluralism, liberalism, purification, religious interpretation 


\section{A. Introduction}

Following the fall of Soeharto from power in 1998, Indonesians began to enjoy the power of free speech. People developed almost all public discourses, religious, social, and political, without fear of state retaliation. One of the most important public religious discourses concerned Islam. Playing an important role in national life, Islam became open to public debate in the post-Soeharto era. Many new groups emerged with a wide range of orientations and a variety of people promoted divergent streams of Islamic thought. According to their backgrounds (social, economic, political, educational, and religious), people lent themselves to a number of categorisations or groupings in Islamic thought.

Liberalism and anti-liberalism are among these groupings. Jaringan Islam Liberal (JIL/Liberal Islam Network), a group of young Muslim intellectuals first coordinated by Ulil Abshar-Abdalla, and Media Dakwah (MD), a publication medium of the Dewan Dakwah Islamiyah Indonesia (DDII/Indonesian Council for Islamic Proselytising) having operated since 1967, are respectively the most significant proponents of liberalism and anti-liberalism in Islamic groupings.

JIL thinkers began their activities in March $2001^{1}$ by establishing a liberal Islam syndicate in Indonesia. ${ }^{2}$ MD (DDII) thinkers first responded to the phenomenon of JIL's liberalism in February 2002 by publishing a special report (in an edition entitled "Militan Bukan Berarti Teroris” [Militant Doesn't Necessarily Mean Terrorist]) criticising liberalism in Indonesian Islam and JIL as well as JIL's basic ideological

1 For more detail of the history of JIL, see "Program Jaringan Islam Liberal", Jaringan Islam Liberal website: http://www.islamlib.com/REDAKSI/jaringan.html (Accessed 21 December 2002); "Tafsir Liberal dari Utan Kayu”, Gatra, no. 3, year VIII (8 December 2001), p. 67; Adian Husaini and Nuim Hidayat, Islam Liberal: Sejarah, Konsepsi, Penyimpangan, dan Jawabannya (Jakarta: Gema Insani Press, 2002), pp. 4-7.

${ }^{2}$ For more detail of the activism of liberal Islam syndicate and its mission, see "Program Jaringan Islam Liberal”,; “Tentang Jaringan Islam Liberal”, Jaringan Islam Liberal website: http://www.islamlib.com/REDAKSI/tentang.html (Accessed 21 December 2002). For the criticism of MD thinkers of JIL's syndicate, see "Penguasa Muslim Tak Jamin Islami”, Media Dakwah, no. 338 (August 2002), p. 49. 
mission. ${ }^{3}$ They followed up this special report with another long report in a subsequent edition, 32 Tabun Gerakan Liberalisme Islam: Nurcholish vs Ibnu Taimiyah [32 Years of Islamic Liberal Movement: Nurcholish vs Ibnu Taimiyah], ${ }^{4}$ condemning liberalism in Indonesian Islam and the activities of JIL thinkers. In order to maintain their opposition to liberalism of JIL thinkers, almost in every issue, MD (DDII) thinkers continued criticising JIL thinkers by discussing them in a wide range of columns.

From such reports, it can be seen that MD (DDII) thinkers have identified JIL as representing the essence of liberal Islam. They conceive of JIL as institutionalising and representing all sorts of liberalism or liberalisation in Indonesian Islamic thought. ${ }^{5}$ This "institutionalisation" (and representation) paves the way for MD (DDII) thinkers to focus on recent liberalism, without neglecting necessary reference to the earlier stream of Islamic liberalism represented by the Gerakan Pembaharuan Islam (Islamic Renewal Movement/IRM).

Hartono Ahmad Jaiz, MD's organic intellectual in the reformasi era, has criticised sharply, accused and condemned, as well as raised the issue of capital punishment against, Abshar-Abdalla and JIL. To add further weight to his criticism of JIL thinkers, Jaiz wrote a specific book on JIL, entitled The Danger of Liberal Islam (Babaya Islam Liberal), ${ }^{6}$ and MD (DDII) further developed it in a number of its issues. In concluding this book, Jaiz quoted a Hadith illustrating the account of 'Umar b. Khattāa (596- 644 AD), who later became the second caliph in Islam, in dealing with the death penalty. It was reported that 'Umar b. Khattāa sentenced one of his companions to death because he was involved in a dispute with a colleague and was dissatisfied with the judgement of the Prophet Muhammad over this dispute. The Prophet Muhammad was himself then reported to have legally justified this action of 'Umar b. Khațāāb. This Hadith, for Jaiz, suggests clearly

${ }^{3}$ Media Dakwah, no. 332 (February 2002).

${ }^{4}$ Media Dakwah, no. 333 (March 2002).

5 See also Khamami Zada, Islam Radikal: Pergulatan Ormas-ormas Islam Garis Keras di Indonesia (Jakarta: Teraju, 2002), p. 97.

${ }^{6}$ Hartono Ahmad Jaiz, Bahaya Islam Liberal (Jakarta: Pustaka Al-Kautsar, 2002).

${ }^{7}$ Ibid., pp. 90-1. 
that Islam, as practised by the Prophet Muhammad and 'Umar b. Khațtāa above, regards as haläl [legally validated] ${ }^{8}$ the death penalty against those who do not accept the judgement of the Prophet, and he accused JIL activists of belonging to this group.

How did such heated debates and responses, which led to the raising of the issue of capital punishment, happen to the relationship between JIL and MD (DDII) thinkers who represent liberal and antiliberal movements respectively? This paper is an attempt to examine the intellectual base of these respective liberal and anti-liberal Islamic movements in the post-Soeharto Indonesian Islam. The intellectual base refers to the concept of religious interpretation upon which the ideas of liberalism and anti-liberalism are developed respectively by JIL and MD (DDII) thinkers. It is engaged, in other words, with the theoretical underpinnings each of the two contesting movements uses to interpret Islam.

The intellectual base takes account of three fundamental aspects of religious interpretations: epistemological assumptions (about basic principles of Islam), methodological framework, and subject-matter. The epistemological assumptions are related to the philosophical foundations or the basic postulations each of JIL and MD (DDII) has about Islam, its function for human beings, and the relationship between it, its producer (God), and its receiver (Man), which serve as the basic principles in Islamic understanding. ${ }^{9}$ Methodological framework means the way each of the two movements understands and interprets Islam and its teachings based on its own philosophical foundations or basic perceptions regarding them. The subject-matter focuses on the facts and ideas which serve as the objects for oral or written pieces of work

8 Ibid., pp. 91-2.

9 This meaning draws on the identification of epistemology by Greco. He argues that as a theory of knowledge, epistemology deals with at least one of the three questions: (1) "what is knowledge?", (2) "what can we know?", (3) "how do we know what we do know?". See John Greco, "Introduction: What is Epistemology", in John Greco and Ernest Sosa (eds.), The Blackwell Guide to Epistemology (Oxford, UK: Blackwell Publishers Inc., 2001), pp. 1-2. 
each of the two movements has produced in Indonesian Islamic thought. $^{10}$

\section{B. Epistemological Assumptions}

Caliph 'Umar b. Khațtāb became an important reference for both JIL and MD (DDII) thinkers. If MD (DDII) thinkers, as expressed by Jaiz above, base their argument for developing the death penalty discourse against Abshar-Abdalla and JIL on this figure, JIL thinkers also consider him as an important reference for their liberal thinking. Ahmad Sahal, one of the key figures behind JIL, argues that 'Umar b. Khaț̣āb developed rationalism in interpreting Islamic texts (the Qur'ān and Hadith). He points out that 'Umar b. Khațtāa even avoided literal interpretation, as appeared in the cases of distribution of war reparations (ghanimah) (the Qur'an 8:41) and of executing the penalty for theft (the Qur'ān 5:38).

... referring to Umar's interpretation, we can see that returning to the Qur'an and the Sunnah is not necessarily identical with literal textualism. Indeed, there is Bilal's model ${ }^{11}$ which tends to be literal. But, there is also another model in Islam, that is 'Umar b. Khatțāb's model, which is very much non-literal. In the literature of Islamic jurisprudence, 'Umar b. Khatțâb's interpretation is referred to as a milestone for the development of a model in Islam which gives priority to rational reasoning in interpreting the Qur'an, which is better known as the madrasah raj. ${ }^{12}$

${ }^{10}$ The meaning of subject-matter in this context draws on the definition by The Oxford English Dictionary. See "Subject-matter", in The Oxford English Dictionary, vol. X, Su-Sz (Oxford: Oxford University Press, 1978), pp. 26-7.

${ }^{11}$ Bilāl was among those companions who sharply opposed the non-literal/ rational interpretation of 'Umar b. Khațāa in those two cases. Due to Bilāl's sharp opposition to him, 'Umar b. Khatțāb said, "Oh God, protect me from Bilāl and his colleagues". It is in this context that Ahmad Sahal identifies Bilāl and 'Umar b. Khaț̣āb as two extreme models in Islamic interpretation, as it is clear in this quotation.

${ }^{12}$ See Ahmad Sahal, "Umar bin Khattab dan Islam Liberal", in Luthfi Assyaukanie (ed.), Wajah Liberal Islam di Indonesia (Jakarta: Jaringan Islam Liberal and Teater Utan Kayu, 2002), pp. 6-7. This article was initially published in Tempo magazine. See Ahmad Sahal, "Umar bin Khattab dan Islam Liberal”, Tempo, no. 5, year XXXI (7 April 2002), pp. 48-9. 
This indicates that JIL and MD (DDII) thinkers differ in their approach to Islamic teachings, especially in dealing with the dialectics between normativity (theological-doctrinal aspects) and historicity (elements of practices) of Islam. JIL thinkers assert that normativity of Islam moves in an interactive dialogue with, and on the same level as, historical experiences of Muslims, meaning that the Islamic teachings (doctrines) are not yet finalised or finished by the revelation of the divine texts in the $7^{\text {th }}$ century. ${ }^{13}$ They maintain that these historical experiences of Muslims represent the application of the normativity in the real context. Borrowing the words of JIL, this perspective "gives emphasis to the spirit of religio-ethical sense rather than to that of literal meaning of the text." 14

The argument of JIL thinkers is similar to that developed by IRM, as represented by Nurcholish Madjid. However, JIL thinkers go further by relating Islam as a universal principle to the acknowledgment of Man's important position as its receiver. Abshar-Abdalla argues, based on the concept of takrim (the recognition by Islam of Man's role in religion, based on the Qur'an 2:30 and 17:70), that Islam "recognises the complexity of human experiences which cannot be undermined or subjugated by the texts which are considered 'universal'." ${ }^{15}$ This is because, he suggests, human beings with all of their experiences constitute an important foundation for their submission to God. ${ }^{16}$ As a result, for Abshar-Abdalla, Muslims' experience in real-life (historicity of Islam) must be incorporated into the interpretation of Islamic normativity or texts, since the Islamic texts are "living and authentic". ${ }^{17}$

MD (DDII) thinkers, however, situate the normativity of Islam in a much higher position than its historicity, meaning that Islamic

\footnotetext{
${ }^{13}$ Sahal, "Umar bin Khattab dan Islam Liberal", p. 5.

14 “"Tentang Jaringan Islam Liberal".

${ }^{15}$ Ulil Abshar-Abdalla, "Menghindari Bibliolatri: Tentang Pentingnya
} Menyegarkan Kembali Pemahaman Islam”, Jaringan Islam Liberal website, 8 February 2004: http://www.islamlib.com/id/page.php?page=article\&id=251 (Accessed 10 February 2003).

${ }^{16}$ Abshar-Abdalla, "Menghindari Bibliolatri".

${ }^{17}$ Ulil Abshar-Abdalla, “Teks, Ortodoksi, Estetika: Sebuah Ketegangan”, in Aswab Mahasin et al. (eds.), Rub Islam dalam Budaya Bangsa: Konsep Estetika (Jakarta: Yayasan Festival Istiqlal, 1996), p. 15. 
teachings (doctrines) were already finalised by the revelation of the texts in $7^{\text {th }}$ century Mecca and Medina. They argue that reinterpretation of the texts (nass.s) of the Qur'an and Hadith, relying on rational reasoning and human experience, is similar to the rejection of the texts themselves. ${ }^{18}$ If this reinterpretation happens, in their opinion, it can be considered heretical. ${ }^{19}$ This implies that while for JIL thinkers, the normativity of Islam must include inputs from the historicity of Muslims to reconstruct its formulation, for MD (DDII) thinkers, the normativity of Islam is one thing and the historicity of Muslims is another, neither of which can be combined.

The argument of MD (DDII) thinkers reminds us of similar one developed by MD (DDII) thinkers in the New Order era, both of which were the same. We can also see that both MD (DDII) thinkers in the New Order and reformasi periods related the normativity of Islam to the literal accounts of the Islamic texts, and accused those who neglected these accounts of being the same as rejecting Islamic texts which become the source of shari'ah.

In turn, positioning normativity and historicity of Islam has given rise to the establishment of a certain attitude towards Islam itself as a religion, and this attitude has become a precondition for the shaping and tendency of a particular Islamic thought which might differ from others. There are two contradictory tendencies (approaches) which dominate the history of Islamic thought: the tendency to sacralise and desacralise text and tradition..$^{20}$ The tendency to sacralise the text and tradition results in the sacralising of the product of Islamic interpretation. ${ }^{21}$ As a consequence, a religious thought must be viewed and taken at face value as itself a religious truth. This kind of tendency

${ }^{18}$ See "Tokoh JIL Disuruh Tobat”, Media Dakwah, no. 342 (December 2002), p. 7; "Tokoh JIL Disuruh Tobat", Media Dakwah, no. 343 (February 2003), p. 38.

19 “Kesesatan Menggerogoti Ummat Islam”, Media Dakwah, no. 347 (May 2003), p. 34.

${ }^{20}$ Komaruddin Hidayat, "Arkoun dan Tradisi Hermeneutika", in Johan Hendrik Meuleman (ed.), Tradisi, Kemodernan dan Metamodernisme: Memperbincangkan Pemikiran Mohammed Arkoun (Yogyakarta: LKiS, 1996), pp. 23-33.

${ }^{21}$ See also Mohammed Arkoun, Al-Isläm: Al-Akblāq wa al-Siyāasah, transl. by Hashỉm Ṣālị̣ (Beirut: Markaz al-Inmā' al-Qawmi, 1990), pp. 171-174. 
presents Islamic interpretation as a divine product and a closed corpus of Islam, not a historical record (legacy) which can be examined. ${ }^{22}$ The tendency to desacralise rejects the tendency to sacralise the text and tradition, and criticises it for disregarding the historical dimension of religious thought. It further accuses the tendency to sacralise of neglecting the fact that the religious thought is a product of time and space, which is historical, and therefore can be examined.

Some Arabic works of Qur'anic exegesis in medieval Islam which have been studied in some Islamic schools in Indonesia, for instance, were mostly produced under situations of conflict, such as the Tartar War, the Crusades, and other conflicts between Muslim and non-Muslim communities. As a result, the ideas of Islam which are developed within these exegetical works cannot be separated from the context of conflict. ${ }^{23}$ This example reveals that the interpretation of Islam is rooted in the history of Muslims in dealing with Islamic normativity and historical experience of life simultaneously.

The heated debate between JIL and MD (DDII) thinkers, as a result, can be discerned as representing the desacralising and sacralising approaches respectively to the text and tradition. While JIL thinkers tend to emphasise the historical dimension, MD (DDII) thinkers tend to play it down. This implies that JIL thinkers open the space for reinterpretation and requestioning of Islamic teachings. In contrast, MD (DDII) thinkers do the opposite, implement the other way around, by closing the space of Islamic teachings from any reinterpretation and re-examination.

If JIL and MD (DDII) thinkers differ in their responses to the relationship between normativity and historicity of Islam, how do they perceive local Arabic tradition in relation to Islamic teachings? While JIL thinkers assume Islamic doctrines as being at a distance from the local Arabic cultural tradition, MD (DDII) thinkers view them as identical. Based on their concept of "relative truth" of religious understanding (for explanation see the subsection "subject-matter" in

${ }^{22}$ M. Amien Abdullah, “Arkoun dan Kritik Nalar Islami”, in Meuleman (ed.), Tradisi, Kemodernan dan Metamodernisme, pp. 9-17.

${ }^{23}$ See interview with Quraish Shihab, "Mengapa Tidak Mengikuti Kesepakatan OKI?", Jawa Pos, 8 December 2002. 
5.2.3 below), JIL thinkers argue that the essence of Islam is not necessarily the same as the Muslim understanding by the time of Revelation. "We have to differentiate between those Islamic teachings which are influenced by Arabic cultural tradition and those which are not, ${ }^{24}$ says Abshar-Abdalla, the organic intellectual of JIL.

JIL thinkers have the same position as IRM thinkers towards local Arabic cultural tradition, but they go further by arguing for the necessity of neglecting this Arab-inspired tradition in practising Islam in Indonesia. "The aspects of Islam which represent Arabic cultural tradition, for instance, do not need to be followed," 25 argues Abshar Abdalla. JIL thinkers further argue that religious understanding is confined to a certain context ${ }^{26}$ and to the existing needs of the interpreter. ${ }^{27}$ This is because the revelation of the Qur'an and Hadith uses Arabic as its historical cultural instrument. ${ }^{28}$ Therefore, both sources of Islam, to some extent, represent "cultural artefacts" (artefak. budaya) whose expressions was limited by cultural articulations at that time of their revelation. ${ }^{29}$ As a result, JIL thinkers believe, if the sociohistorical context changes from the time of Revelation and the setting of local Arabic tradition, the Islamic interpretation must also change. ${ }^{30}$

${ }^{24}$ Ulil Abshar-Abdalla, “Menyegarkan Kembali Pemahaman Islam”, Kompas, 18 November 2002. See also this quotation in Ulil Abshar-Abdalla, "Menyegarkan Kembali Pemahaman Islam", in Ulil Abshar-Abdalla et al., Islam Liberal dan Fundamental: Sebuah Pertarungan Wacana, $2^{\text {nd }}$ edition (Jogjakarta: eLSAQ Press, 2003), p. 2.

${ }^{25}$ Abshar-Abdalla, "Menyegarkan Kembali Pemahaman Islam”, p. 2.

${ }^{26}$ Ulil Abshar-Abdalla, "Membangunkan Kembali Islam", an introduction to Nur Khalik Ridwan, Islam Borjuis dan Islam Proletar: Konstruksi Baru Masyarakat Islam Indonesia (Yogyakarta: Galang Press, 2001), pp. xii and xvii.

27 "Tentang Jaringan Islam Liberal".

${ }^{28}$ For more detail of this issue, see personal correspondence between AbsharAbdalla and Nur Abdurrahman, "Dialog Ulil Abshar-Abdalla - HM Nur Abdurrahman", posted by Dwi W. Soegardi on Jaringan Islam Liberal (JIL) Mailing List, 23 December 2002: 1 slamliberal@yahoogroups.com (Accessed 23 December 2002). The materials of this dialogue were later published in a book, and such a quotation can be found inside. See correspondence between Abshar-Abdalla and Nur Abdurrahman, "Wahyu itu Non-historis sekaligus Historis", in Abshar-Abdalla et al., Islam Liberal dan Fundamental, pp. 216-56.

${ }^{29}$ Abshar-Abdalla, "Membangunkan Kembali Islam", p. xii.

${ }^{30}$ Sahal, "Umar bin Khattab dan Islam", pp. 6-7. 
On the other hand, MD (DDII) thinkers are convinced that Islamic doctrines, as revealed in the Qur'an and Hadith, and the local Arabic tradition which became the context of their revelation, are interrelated, ${ }^{31}$ a religious conviction which was also similarly developed by MD (DDII) thinkers in the New Order era. This strongly conveys that MD thinkers in the reformasi era do not further develop the argument which was delivered by MD thinkers in the New Order era. Both generations of MD thinkers just believed that $7^{\text {th }}$ century Islamic doctrines are immune to any socio-historical setting and change in Indonesia even though this setting and change have different features from those doctrines.

There is no difference in the developing of the main argument, especially concerning Western civilisation from the perspective of Islam-tradition relationship, between either supporters of liberalism in the New Order and reformasi periods or those of anti-liberalism in those two eras. Like IRM activists, JIL thinkers, while to some extent being critical of, adopt and appreciate the positive products of Western civilisation, such as modernity and its results, including the health system and social security. ${ }^{32}$ Both wings of liberal thinkers based their argument on the positive values of Western civilisation for modernisation of Indonesia. Similar to MD (DDII) activists in the New Order era, MD (DDII) thinkers in the reformasi period accuse the West, especially its system of values, as being contradictory to, and therefore the enemy of Islam. However, MD (DDII) thinkers in the latter period add an

${ }^{31}$ The discussion of MD thinkers on this issue is further developed in their responses to the ideas of Ahmad Wahib, one of the figures behind the liberalism in the New Order Indonesian Islam, on the relationship between the Qur'an, Hadith and Arabic cultural tradition. See "Bahaya Islam Liberal (3): Lanjutan Edisi Februari 2002M", Media Dakwah, no. 333 (March 2002), p. 33.

${ }^{32}$ See Abshar-Abdalla's appreciation of Western civilization in his writings: "Re: Curhat Saya: Masih Soal Aswaja”, KMNU2000 Mailing List, 26 May 2003: kmnu2000@yahoogroups.com (Accessed 27 May 2003); “Re: Berpikir Obyektif”, Jaringan Islam Liberal Mailing List, 28 July 2003: islamliberal@yahoogroups.com (Accessed 29 July 2003); "Oleh2 dari Australia", Jaringan Islam Liberal Mailing List, 22 July 2003: islamliberal@yahoogroups.com (Accessed 23 July 2003); “Oleh2 dari Australia (2)”, Jaringan Islam Liberal Mailing List, 22 July 2003: islamliberal@yahoogroups.com (Accessed 23 July 2003). 
argument that the West develops the principles of individualism, secularism, and anthropocentrism (Man-based theology), whereas Islam promotes the principles of collectivism (berjama'ab) and appeals for good conduct based on divine order (al-amr bil-ma'rüf wa'l-naby 'an almunkar/"calling for the good and prohibiting the evil"). ${ }^{33}$

Concerning the non-Arabic local tradition, even though equally appearing more sympathetic and accommodating, JIL thinkers go further than IRM thinkers by arguing for the inevitability of variety of Islam in real-life. Abshar-Abdalla argues that Islam certainly continues to develop in a variety of cultural traditions. Islam, he further argues, changes its expression in light of the existing cultural tradition. As a result, he specifically argues, "Islam is obviously varied (warna-warni); there being no single Islam." ${ }^{34}$ In contrast, there is no difference between MD (DDII) thinkers in the New Order and reformasi eras in their responses to non-Arabic local tradition. Both generations of MD (DDII) thinkers just believe that local tradition (adat) is identical with deviant faith and therefore becomes the "main enemy" of shari' $a{ }^{35}$. As a result,

${ }^{33}$ Personal interview with Hartono Ahmad Jaiz in the office of LPPI, Jakarta, 16 January 2004; "Impor", Media Dakwah, no. 348 (June 2003), 41. As an example, one of the Western products of civilisation which is perceived by MD thinkers as the opposite of Islam is its knowledge and science on Islam. It is in this context that MD is opposed to the phenomenon of Indonesian Muslims pursuing Islamic studies in Western universities. See "Jejak Kristen dalam Islamic Studies”, Media Dakwah, no. 347 (June 2003), pp. 48-9.

${ }^{34}$ Ulil Abshar-Abdalla, "RE: Apakah "Yang Pribumi” Bisa Berbicara?—Buat Hamami (4)", Jaringan Islam Emansipatoris Mailing List, 7 October 2003: emansipatoris@yahoogroups.com (Accessed 7 October 2003); idem., "Islam WarnaWarni”, Jaringan Islam LiberalWebsite, 11 August 2002: http://www.islamlib.com/id/ page.php?page $=$ article\&id $=236$ (Accessed 10 October 2003). See also Ulil Abshar-Abdalla, "Keragaman dalam Pandangan Islam", in M. Imdadun Rahmat et al., Islam Pribumi: Mendialogkan Agama, Membaca Realitas (Jakarta: Erlangga, 2003), pp. 115-9. The idea of JIL thinkers on "Islam Warna-Warni" has been promoted as the social advertisement on several Indonesian Television channels, and has also been protested by the Majelis Mujahidin Indonesia (MMI/Indonesian Mujahidin Council) to be stopped from its broadcasting. See "Disesalkan, Penghentian Sepihak Tayangan 'Islam Warna-Warni”, Kompas, 14 August 2002.

35 "Pengusung Adat dan Aliran Sesat: Musuh Utama Syari'at", Media Dakwah, no. 338 (August 2002), pp. 33-49. 
they are convinced that Islam is one, not many as believed by JIL thinkers.

Following the difference in attitudes towards non-Arabic cultural traditions, there is a divergence in responses towards the local and contemporary contexts of Islam between the two movements. ${ }^{36} \mathrm{JIL}$ thinkers welcome the role of the local and contemporary contexts of the religious doctrines and their significance in the social life of Indonesian Muslims at the existing moment. ${ }^{37}$ As a result, they assert that Islamic doctrines must be brought into dialogue with the existing conditions of Islam and those of its believers in contemporary Indonesia. This has resulted in the adoption of "Islamic rethinking". JIL thinkers suggest this rethinking of Islam is important due to the fact that "a certain religious interpretation, in one or another way, is a mirror of the contextual need of an interpreter in a certain time and space, which changes over time." ${ }^{38}$ This idea of JIL thinkers conveys similar arguments as what IRM thinkers developed for their Islamic renewal thinking, both of them were based on the future-oriented values.

MD (DDII) thinkers, however, argue for the principle that the textual role of Islamic doctrine has to be held up irrespective of the existing socio-historical conditions which are faced by Indonesian Muslims. In their opinion, the textuality of the Revelation must be placed in a higher position than the existing social conditions as well as than human power of reason. MD (DDII) thinkers, such as Rucita, ${ }^{39}$ accuse JIL of having arbitrarily changed many stipulations necessitated by the qat $i$ (definite) texts of the Qur'an, such as the verses of chapter 2:221 and chapter 3:19. They also accuse JIL of altering these texts

${ }^{36}$ For more detail on the idea of liberalism and anti-liberalism in contemporary Indonesian Islamic thought regarding the textual role of Islamic doctrines and religious practices of early Islam, see an Indonesian article by Akh. Muzakki, "Otentisitas, Problem Dasar Islam”, Media Indonesia, 2 May 2003.

${ }^{37}$ See also Zuly Qodir, Islam Liberal: Paradigma Baru Wacana dan Aksi Islam Indonesia (Yogyakarta: Pustaka Pelajar, 2003), p. 183.

38 “Tentang Jaringan Islam Liberal”.

${ }^{39}$ Ceceng Rucita, "JIL dan Logika Iblis”, Media Dakwah, no. 336 (June 2002), p. 16 . 
when they perceive them as being incompatible with the existing reality or conditions, especially in relation to modernism, capitalism, human rights, democracy, and pluralism. ${ }^{40}$ This implies that $\mathrm{MD}$ thinkers require that Islamic doctrines be preserved in such a way that the existing conditions do not alter their literal meaning.

Analysing the argument developed by both MD thinkers in the New Order and reformasi eras, it is clear that there is no difference between these two generations of anti-liberal thinkers in their attitudes towards Islamic texts, both of them adhered to literal perspective in understanding Islamic teachings. This perspective led both of them to be unaware of the changing social circumstances faced by Muslims in Indonesia.

\section{Methodological Framework}

Haidar Bagir, an Indonesian Muslim intellectual, is among those who criticise Abshar-Abdalla and JIL for their methodological framework in interpreting Islamic teachings. ${ }^{41}$ Bagir argues that the liberalism of Abshar-Abdalla and his JIL has long been developed in Islamic history, both with the support of and criticism from Muslims. As a result, he suggests, there is a precedent for their liberal thinking in Islamic history. However, he goes on to say, they have to declare their methodological framework in Islamic interpretation in order to dismiss the impression of arbitrariness. He encapsulates his argument as follows:

I worry that the problem of Ulil [Abshar-Abdalla]'s article is -againthe absence of declaring the methodological framework which guides his attempt to draw conclusions. As a result, I worry [again], that the only impression left to some of the audience is arbitrariness and a lack of basic foundations [of his attempt] for drawing those conclusions. It has been reported, however, that Ulil [Abshar-Abdalla] was recently

\footnotetext{
${ }^{40}$ Rucita, "JIL dan Logika Iblis", p. 16.

${ }^{41}$ See other critiques in Syamsul Arifin, "Liberalisme Islam Minus Epistemologi”, in Islam Indonesia: Sinergi Membangun Civil Islam dalam Bingkai Keadaban Demokrasi (Malang: UMM Pres, 2003), p. 187.
} 
focusing on the arrangement of methodology for formulating the views of Jaringan Islam Liberal. ${ }^{42}$

JIL thinkers reject the criticism of Bagir by saying that JIL does not restrict its methodological framework to any particular kind. They argue that they accept any methodological framework provided that it aims to liberate Muslims from any intellectual stagnation and conservatism. Fundamental to this framework is "the critical awareness" which "liberates God from any religious tradition" in order for religion to become the source of energy for the progressive movement (gerak maju) of the ummah (Muslim community) towards a better state of life. ${ }^{43}$

MD (DDII) thinkers accuse JIL activists of being methodologically ungrounded, based on the fact that they do not declare their methodological framework. As a result, they insist, the methodological framework of the liberalism of JIL thinkers is not academically strong enough to interpret Islamic teachings. ${ }^{44}$ Adian Husaini, an active contributor to MD, even argues that the liberalism of JIL thinkers represents nothing more than "intellectual coquettishness" (kegenitan intelektual). He specifically accuses JIL thinkers of having superficial methodology. ${ }^{45}$ Thus the methodological framework has become a crucial issue in Islamic understanding.

In order to examine the framework of thinking of JIL and MD (DDII) thinkers in approaching Islamic teachings methodologically, however, there are some significant issues which deserve a closer

${ }^{42}$ Haidar Bagir, “Beberapa Pertanyaan untuk Ulil”, Kompas, 4 December 2002. This article was later compiled in a book on the discourse of liberal and fundamentalist Islam in Indonesia. See Haidar Bagir, "Beberapa Pertanyaan untuk Ulil Abshar-Abdalla", in Abshar-Abdalla et al., Islam Liberal dan Fundamental, pp. 116-20.

${ }^{43}$ Samsu Rizal Panggabean, "Prospek Islam Liberal di Indonesia", in Assyaukanie (ed.), Wajah Liberal Islam, p. 9. Another objection to Bagir's criticism comes from Hamid Basyaib, another leading figure behind JIL. He insists that JIL represents more as a forum for brainstorming among the Muslim activists rather than a school of Islamic thought. For more detail, see Hamid Basyaib, "Islib Butuh Metodologi?: Tanggapan untuk Haidar Bagir", Republika, 23 March 2002.

44 “Islam Liberal dan Misinya", Media Dakwah, no. 332 (February 2002), p. 14.

${ }^{45}$ Adian Husaini, "Liberalisasi Islam di Indonesia: Dekonstruksi, Belum Rekonstruksi”, Aula (January 2003), p. 39. 
examination. These issues include: (1) the theoretical approach to Islamic textuality, (2) the source of intellectual creativity in interpreting Islamic teachings, (3) the role of the Islamic intellectual legacy in interpreting Islamic texts, (4) the concept of history, and (5) the relationship between the power of human reason and Revelation.

JIL and MD (DDII) thinkers have a fundamental difference in approaching Islamic textuality. Liberal thinkers of JIL view the Qur'anic texts and Hadith more from the perspective of universal moral values (maqäsid al-shari'ab), which are developed within the text, than the literal accounts of the texts themselves; a principle which was also part of IRM's main arguments. As a result, they largely welcome reinterpretation processes of the meaning of the text through a diversity of methodology, which requires an optimal benefiting of human intellect. These reinterpretation processes can be undertaken, they argue, if the socio-historical context faced by a certain society in a particular situation is dissimilar to that in the period of the revelation of the text. ${ }^{46}$

MD (DDII) thinkers claim that this method of reinterpretation by JIL thinkers opposes and rejects the nass (text) itself. The fact that JIL thinkers may neglect the texts by embracing the universal moral values of Islam (maqāsid al-shari'ah) has made MD thinkers accuse them of being identical with the devil. This accusation is based on their argument that like JIL ignoring the text using those universal moral values as the set standard, the devil also rejected the divine order to submit (sujūd) to Ādam using qiyas (analogy) for its reasoning that it was created from the fire (al-när) but $\bar{A} d a m$ was from the soil $(a l-t i n) .{ }^{47}$

JIL thinkers are inspired by the success of modern Western civilisation. Above all, as far as this thesis is concerned, the ideas

\footnotetext{
${ }^{46}$ Sahal, "Umar bin Khattab dan Islam Liberal", pp. 4-8.

${ }^{47}$ See article of "wawasan [insight]" by Rucita, "JIL dan Logika Iblis", 17; "Tokoh JIL Disuruh Tobat”, Media Dakwah, no. 342 (December 2002), p. 7.
} 
produced by JIL thinkers are generally based on Western concepts, ${ }^{48}$ such as those of Islam and democracy. This fact is not random, but rather seems to go along with the attempt of Indonesian Muslims to modernise their life. As part of this attempt, they argue for promoting a greater role for Islam in national life and denounce Islamist concepts, such as Islamic state. Martin et al. eloquently illustrate the tendency of contemporary Indonesian Islamic thought, saying:

Indonesian Muslim intellectuals are increasingly concerned with the questions of the proper role of Islam in national development and how Islamic values can be reconciled with Western rationalism, rather than with the nature of an Islamic state. Routine religious questions in theology (kaläm) and Islamic law (fiqh) are still debated but are not among the central concerns of contemporary intellectuals. ${ }^{49}$

MD (DDII) thinkers are inspired by the civilisation which has been developing in the Middle East. They always report, and are concerned with, issues in Middle Eastern Islam. This does not mean that they do not attain inspiration from other areas, such as from within Indonesia. As indicated below, Indonesian real-life has become the local context for the dynamics of MD (DDII) thinkers' intellectualism.

${ }^{48}$ Mohamad Ihsan Alief (Ihsan Ali Fauzi), a founding member of JIL, also supports this argument. Identifying JIL thinkers' production of ideas, he says that "they depend too much on Western sources in defending their ideas, and therefore are susceptible to identification with a Western agenda." See Mohamad Ihsan Alief, "Political Islam and Democracy: A Closer Look at the Liberal Muslims", Asia Program Special Report, no. 110 (April 2003), p. 14. In his MA thesis, Harjanto also indicates JIL's high reference to Western concepts by saying that "The problems related to the domination of modernization paradigm or Western development thinking and the lack of methodological basis are issues that JIL activists should address in elaborating its [or their] distinctive interpretation of Islam." Based on these problems, he argues, it is urgent for JIL thinkers to shed light on their methodological approach, whether they would like to "liberalise" Islam or to "Islamise" liberalism. This is because, he further argues, both approaches have different consequences in the philosophy of ethics, political theory, and critical theories. For more detail, see Nicolaus Teguh Budi Harjanto, "Islam and Liberalism in Contemporary Indonesia: The Political Ideas of Jaringan Islam Liberal (The Liberal Islam Network)", (Unpublished MA Thesis, College of Arts and Sciences, Ohio University, Athens, 2003), p. 83.

${ }^{49}$ Richard C. Martin et al., Defenders of Reason in Islam: Mu'tazilism from Medieval School to Modern Symbol (Oxford, England: Oneworld Publications, 2003), p. 148. 
Pertinent to this is MD's rejection of Western intellectualism in relation to issues concerned with Islamic teachings. In Jaiz's view, this rejection is based on the belief in two aspects of authority in Islamic knowledge: intellectual capacity (keablian ilmu) and individual practices (amaliyah). Jaiz rejects Western scholars since they do not believe in and practise Islamic teachings despite their capability in Islamic knowledge. ${ }^{50}$

Apart from the difference in approach to Islamic textuality, there is a difference between liberal and anti-liberal thinkers in what they perceive the role of the Islamic intellectual legacy in interpreting Islamic texts to be. The argumentation of Abshar-Abdalla and JIL in this respect appears to be based on the formula of al-mubäfazah 'ala al-qadim alsalith wa al-akbdh bill-jadid al-aslạ. [maintaining the old which is good, and taking the new which is better], a principle which was also developed by IRM thinkers. Abshar-Abdalla argues that Muslims have to implement ijtihäd (rational argumentation) in order to search for a new formula for translating the universal values of Islam, as contextually practised by early Muslims, into the recent context of their real-life. ${ }^{51}$ He further argues, "In my opinion, the development of intellectual thinking operates in this way: one generation relies on a previous one; nothing is really new in this world; all is cumulatively inter-reliant on the other." ${ }^{52}$

In response to particular issues which were typical of the age of Revelation, Abshar-Abdalla notes that "We [Muslims] need to refer to the historical records [thoughts] produced by the exegetes (mufassirs)." ${ }^{\prime 3}$ However, these historical records, in his view, do not necessitate the exact meaning of Islamic teachings (such as the stipulation expressed in the case of zakāh with formula 1:2 for man and woman), but has to

${ }^{50}$ Personal interview with Hartono Ahmad Jaiz in the office of LPPI, Jakarta, 16 January 2004.

${ }^{51}$ Abshar-Abdalla, "Menyegarkan Kembali Pemahaman Islam”, p. 4.

${ }^{52}$ Ulil Abshar-Abdalla, "RE: Wawancara Afkar dgn Ulil Abshar-Abdalla", KMNU2000 Mailing List, 01 December 2003: kmnu2000@yahoogroups.com (Accessed 02 December 2003).

${ }^{53}$ See personal correspondence between Abshar-Abdalla and Nur Abdurrahman, "Dialog Ulil Abshar-Abdalla - HM Nur Abdurrahman". See also "Wahyu itu Nonhistoris sekaligus Historis", in Abshar-Abdalla et al., Islam Liberal dan Fundamental, p. 236. 
be contextualised with the spirit of the age (which might change the formula to 1:1 based on the social context). ${ }^{54}$ As a consequence, if the recent result of contextualisation is more relevant to contemporary life than the historical records of Muslims in the past, it can be taken as a reference for Muslim practices.

It is for the sake of carrying out this contextualisation of the text and tradition that JIL thinkers welcome any methodologicaltheoretical means to interpret Islamic teachings, not only taken from Islam but also from other traditions. Abshar-Abdalla, for instance, incorporates hermeneutics (meaning "the art of interpretation"), which is an example of a theoretical tool from another intellectual tradition, and ta'wil (reasoning), which comes from Islamic tradition, into one methodological tool for analysing Islamic teachings. He states that hermeneutics can be used as an intellectual tradition which is helpful to re-understand Islamic teachings, as conveyed in the Qur'an and Hadith. $^{55}$

MD (DDII) thinkers reject the contextualisation of Islamic texts and idealise the intellectual legacy of early Muslim thinkers. They quote a number of Muslim thinkers, whom they regard as the great exegetes (para mufassir agung), and whose ideas are used as their references. They include Ibn 'Abbās, al-Qurțūbi, Ibn Kathìr, Sayyid Quṭb, and Abūl A'lā al-Mawdūdi. ${ }^{56}$ It is clear therefore that they always refer to the works of Muslim thinkers in the past when they attempt to interpret Islamic teachings. As a result, they reject intellectual traditions other than Islamic

${ }^{54}$ See personal correspondence between Abshar-Abdalla and Nur Abdurrahman, "Dialog Ulil Abshar-Abdalla - HM Nur Abdurrahman". See also "Wahyu itu Nonhistoris sekaligus Historis", in Abshar-Abdalla et al., Islam Liberal dan Fundamental, p. 251.

${ }^{55}$ Abshar-Abdalla's view of the possible using of hermeneutics and ta'wil for Islamic interpretation can be seen in his articles, "Allahu Akbar (Minal 'Teks')", Tempo, No. 26, year XXXI (26 August - 01 September 2002), 58; idem., "Menyegarkan Kembali Pemahaman Islam”, pp. 1-9. See also personal correspondence between Abshar-Abdalla and Nur Abdurrahman, "Dialog Ulil Abshar-Abdalla - HM Nur Abdurrahman"; "Wahyu itu Non-historis sekaligus Historis", in Abshar-Abdalla et al., Islam Liberal dan Fundamental, pp. 221. See also JIL's view in “Tentang Jaringan Islam Liberal”.

56 "Hermeneutika, Tafsir al-Qur'an, dan Tokoh Muhammadiyah", Media Dakwah, no. 348 (July 2003), p. 24. 
legacy, such as hermeneutics. They argue that this discipline of knowledge cannot be used for interpreting Islamic teachings since it is an intellectual tradition of biblical studies. ${ }^{57}$

Since JIL thinkers overwhelmingly welcome hermeneutics as a possible method for interpreting Islamic teachings, MD (DDII) thinkers manoeuvre to oppose them by referring to an article "Tafsir Bukanlah Hermeneutika" [Tafsir is not Hermeneutics] written by Wan Mohd Nor Wan Daud, a prominent Malaysian thinker who opposes the use of hermeneutics. ${ }^{58}$ They appear to have deliberately published this article to promote their idea of the Islamisation of science and their networking with the Malaysia-based International Institute of Islamic Thought and Civilisation (ISTAC), since Wan Daud became its director. ${ }^{59}$ The publication of this article also challenges the authority of liberal thinkers in Indonesia, since like Nurcholish Madjid, Wan Daud is a former student of Fazlur Rahman at the University of Chicago, but has a different thinking about hermeneutics. ${ }^{60}$

JIL and MD (DDII) thinkers differ in their concept of history. This can be seen through their views of the relationship between Islam and human development. JIL thinkers, as expressed by Abshar-Abdalla, develop the concept of progressive history in the sense that "human life continuously moves forward towards improvement and perfection." ${ }^{\prime 1}$ As a result, they conceive of Islam as a religion which develops these progressive values, by indicating that "its authenticity

${ }^{57}$ See "Hermeneutika, Tafsir al-Qur'an, dan Tokoh Muhammadiyah", p. 24; Syamsul Bahri Isma'iel, "Islam Liberal: Menafsirkan Agama dengan Hermeneutika Barat”, Media Dakwah, no. 334 (April 2002), pp. 24-5.

${ }^{58}$ See an article by Wan Mohd Nor Wan Daud, "Tafsir Bukanlah Hermeneutika”, Media Dakwah, no. 348 (July 2003), pp. 25-32.

${ }^{59}$ ISTAC was set up in 1991 few months before the inception of Ikatan Cendekiawan Muslim Se-Indonesia (ICMI/The Association of Indonesian Muslim Intelligentsia). It was first chaired by Anwar Ibrahim, and came under the patronage of Syed Naquib al-Attas. Recently, it was led by Wan Daud. For more detail, see Farish A. Noor, 'The Challenges and Prospects for 'Progressive Islam' in Southeast Asia: Reclaiming the Faith in the Age of George Bush and Osma ben Laden", (Paper presented for the Centre for Modern Orient Studies, Berlin, 2004), pp. 21-2.

60 "Hermeneutika, Tafsir al-Qur'an, dan Tokoh Muhammadiyah", p. 24.

${ }^{61}$ Abshar-Abdalla, "Menyegarkan Kembali Pemahaman Islam”, p. 4. 
does not only move backward, but has also to move forward." ${ }^{2}$ This idea of Abshar-Abdalla essentially has similarity to the idea of progress which was developed by Madjid during the New Order era. Above all, Abshar-Abdalla notes that Islam is a living organism which develops in accordance with the pace of human development. He insists that Islam is not an old fossil (monumen mati) which grew in the $7^{\text {th }}$ century and accepted no historical intervention.

The perception of Islam as a living organism results in a particular humanistic understanding of the Prophet Muhammad's historical role in conveying Islamic teachings. Abshar-Abdalla regards the Prophet Muhammad as a historical figure who deserves a critical analysis in the sense that he must be understood as not only a revered mythical figure, but also as a man who, like others, had strengths and weaknesses. ${ }^{63}$ "Do we have to say that the Prophet is an angel?," says Abshar-Abdalla. ${ }^{64}$ The Islam which was practised in Medina by the Prophet Muhammad, he argues, constituted a historical, particular, and contextual Islam. As a result, he says, "We are not obliged to follow the Prophet at face value, since his practices in Medina represented attempts to negotiate the universal values of Islam with the social conditions there with all of their hindrances." ${ }^{\prime 5}$

In contrast, MD (DDII) thinkers conceive of history as confined to the literal account of Islamic texts. Jaiz argues that as long as there is a divine order as it appears in the texts, the pace of human development has to follow it. Muslims, for him, cannot undertake the reverse by fitting the divine order to the pace of human development. They should not say, in his view, that the divine order is no longer relevant to the current situation, since God knows the best for Man, as expressed in the Qur'an 95:8. ${ }^{66}$

Since their concepts of history are different, JIL and MD thinkers also differ in viewing the relationship between the power of human

\footnotetext{
${ }^{62}$ Abshar-Abdalla, "Membangunkan Kembali Islam", p. xiv.

${ }^{63}$ Abshar-Abdalla, "Menyegarkan Kembali Pemahaman Islam", p. 4.

${ }^{64}$ See interview with Ulil Abshar-Abdalla, "Apa Saya Harus Mengatakan Nabi itu Malaikat”, Tabloid Warta (January 2003), p. 9.

${ }^{65}$ Abshar-Abdalla, "Menyegarkan Kembali Pemahaman Islam”, p. 4.

66 "Tokoh JIL Disuruh Tobat", p. 38.
} 
reason and Revelation. Based on the concept that Islam is a living organism, Abshar-Abdalla argues that Revelation did not stop with the death of the Prophet Muhammad, but continues progressively to be handed down to the people in context with time and place. He calls this principle "progressive Revelation". ${ }^{67} \mathrm{He}$ furthermore classifies Revelation into two types: verbal and non-verbal. He explains that "Verbal Revelation was completed in the Qur'àn, but non-verbal Revelation continues to be handed down to people in recent times in the form of human intellect-based ijtibäd." ${ }^{68}$ Thus, for Abshar-Abdalla, while verbal Revelation is Qur'anic texts, non-verbal Revelation is the human power of reason.

Abshar-Abdalla views human reason as a supporting facility given to Man in order to maintain Revelation as the source of morality. $\mathrm{He}$ argues, "Human reason constitutes an active participant in interpreting divine ideas which are contained in the Revelation." ${ }^{69}$ The function of human reason, according to him, is to purify Revelation from any abuse by people for their vested interests. This is because, he suggests, people can abuse the power of Revelation in such a way that the human power of reason loses its capacity to understand the essence of Revelation.

Revelation can elevate the dignity of human reason to a higher position and quality in order for it to comprehend the bounds [of decency]. However, Revelation can [also] bring human power of reason into decline when it suffers 'vulgarisation,' meaning that Revelation is abused for the sake of temporary-worldly interests. In order for Revelation to be able to revive and attain its integrity again as the source of morality, human power of reason which is full of responsibility and of integrity is badly needed. ${ }^{70}$

${ }^{67}$ Ulil Abshar-Abdalla, "Wahyu Progresif”, in Assyaukanie (ed.), Wajah Liberal Islam, 74-7; Interview with Abshar-Abdalla, "Islam Liberal", p. 8.

${ }^{68}$ Abshar-Abdalla, "Menyegarkan Kembali Pemahaman Islam”, p. 4.

${ }^{69}$ Ulil Abshar-Abdalla, "Agama, Akal, dan Kebebasan: Tentang Makna 'Liberal' dalam Islam Liberal”, Jawa Pos, 11 May 2003. This article was later re-published on JIL website. See Ulil Abshar-Abdalla, "Agama, Akal, dan Kebebasan: Tentang Makna 'Liberal' dalam Islam Liberal", Jaringan Islam Liberal website, 11 May 2003: http:// www.islamlib.com/id/page.php?page=article\&id=208 (Accessed 13 May 2003).

${ }^{70}$ See Abshar-Abdalla, "Agama, Akal, dan Kebebasan". 
MD (DDII) thinkers, in contrast, argue (as indicated above) that Revelation had been finalised and completed by the death of the Prophet Muhammad, a principle which was also believed by MD thinkers in the New Order era. This finalised Revelation, for them, is in the Qur'anic texts and Hadith. This means that the human power of reason has to follow divine orders, as contained verbally in the Revelation. As indicated above as well, MD thinkers believe that the essence of Revelation resides in the verbatim accounts of the texts. As a result, they also believe that it is not possible for human reason to go beyond the literal accounts of the texts. Going beyond the literal accounts of texts, in their view, can be seen as the same as rejecting the texts themselves.

\section{Subject-matter}

To discuss the heated debates at the level of the subject-matter, it is necessary to list the "thought agenda" of JIL, which consists of six main elements: (1) Opening the gate of ijtihād for all aspects of Islam; (2) Emphasising the religio-ethical rather than the literal sense of the text; (3) Identifying truth as relative, open, and plural; (4) Sympathising with the minority and the oppressed; (5) Freedom of religion; and (6) Separation between mundane and spiritual authority, and between religious and political authority. ${ }^{71}$ Gatra, a Jakarta basedweekly magazine, refers to this agenda as the "Manifesto of JIL". ${ }^{72}$

It is important to note that in the context of Indonesian Islam, the term "liberal Islam" emerged in provocative ways for the first time when Greg Barton's dissertation was published in Indonesian by the Madjid-led Paramadina Foundation. The editors of Barton's book gave it the title "Ideas of Liberal Islam in Indonesia" (Gagasan Islam Liberal

\footnotetext{
71 “Tentang Jaringan Islam Liberal".

${ }^{72}$ See "Manifesto Jaringan Islam Liberal", Gatra, no. 2-3, year X (6 December 2003), p. 108.
} 
di Indonesia). ${ }^{73}$ It is also important to note, however, that the first use of this term by Paramadina did not, in fact, evoke a controversy as large as the current one involving JIL thinkers. ${ }^{74}$

There are two important reasons for this fact. First, Paramadina did not follow up the first emergence of the term "liberal Islam" by taking more practical actions for this discourse, such as providing guidelines for practising liberal ideas through active campaigning. This differs from the later development, in which JIL thinkers not only used the term "liberal Islam" in their discourse, but also developed it as the ideology and identity of their movement. More importantly, JIL thinkers continue to promote this concept of liberal Islam in their discussion of actual and tangible issues.

Second, a strong impression has emerged that the involvement of foreign sponsors in financing the socialisation of liberalism in Islamic thought has become an important factor in dividing the responses of the Muslim community concerning the emergence of "liberal Islam". When first promoted by Paramadina, the socialisation of "liberal Islam" did not have any foreign sponsorship. In contrast, JIL thinkers have developed liberalism in Islamic thought through receiving financial assistance from foreign institutions, such as The Asia Foundation (TAF). In the view of anti-liberal groups, the involvement of foreign sponsors (especially Western) is a problem because it represents possible intervention which they regard as potentially destroying Islam itself. Hence, they accuse the liberal movement of JIL thinkers of representing foreign interests, and not the interests of internal Indonesian Islam. This can be seen through their claim that without The Asia Foundation (TAF), JIL is nothing, since for them the strength of JIL thinkers is

${ }^{73}$ For more detail, see Greg Barton, Gagasan Islam Liberal di Indonesia: Pemikiran Neo-Modernisme Nurcholish Madjid, Djohan Effendi, Abmad Wabib, dan Abdurrahman Wabid, 1968-1980 (Jakarta: Pustaka Antara-Paramadina, 1999). Compare this with the English version as appeared originally in Greg Barton, "The Emergence of Neo-Modernism; A Progressive, Liberal, Movement of Islamic Thought in Indonesia: A Textual Study Examining the Writings of Nurcholish Madjid, Djohan Effendi, Ahmad Wahib and Abdurrahman Wahid 1968-1980”, (Unpublished Dissertation, Monash University, Victoria, Australia, 1995).

${ }^{74} \mathrm{JIL}$ thinkers, as represented by Ahmad Sahal, also confirm this fact. Personal interview with Ahmad Sahal in the Freedom Institute, Jakarta, 12 January 2004. 
their foreign financial assistance. ${ }^{75}$

In order to reveal how JIL and MD (DDII) thinkers have differed in their production of ideas, what follows is an analytical examination of the subject-matter developed by both groups of thinkers. For the purpose of this examination, six main elements of "thought agenda" promoted by JIL are selected as the frame of analysis.

\section{Opening the Gate of Ijtibäd for All Aspects of Islam}

JIL thinkers argue that $i j t i b \bar{a} d$ is the main principle by which Islam can adapt to any context. Defined as the use of rational reasoning to interpret Islamic texts, ijtihäd for them can be practised by all Muslims. They argue that forbidding the use of ijtibäd can be seen as a serious threat to Islam itself, since Islam will suffer decay (pembusukan). Even though they maintain that the practice of ijtibäd in matters of religious ritual ("ubüdiyah) must be done with caution, they believe that "ijtibäd can be applied to most aspects of religion, from theology (iläbiyah) and ritual ('ubüdiyah) to -the more so- social interaction (mu'amalab)."'76

MD (DDII) thinkers support the restricted use of ijtihad if it is confined to those aspects of Islam not considered as primary (ușil) but secondary $\left(f u r \bar{u}^{\prime}\right.$ ) or silenced/unelaborated (masküt 'anh). They define primary aspects as those issues which have been explained by the dalil (legal indicator/evidence) in the Qur'an and Hadith in such a firm, lucid and unambiguous way that agreement, rather than disagreement, emerges among Muslims. They argue that these primary aspects are related to Islamic 'aqidah, such as the six pillars of iman (faith). They claim those who disagree with these primary aspects have strayed from the path of Islam. As a result, there is no room for ijtiha $\bar{a} d$ in these aspects. $^{77}$

${ }^{75}$ Personal interview with Moh Syah Agusdin, the executive editor of MD, in the office of MD, Jakarta, 16 January 2004; personal interview with Hussein Umar in the office of DDII, Jakarta, 19 January 2004.

76 “Tentang Jaringan Islam Liberal".

${ }^{77}$ See "Kesesatan Menggerogoti Ummat Islam", pp. 33-36. At the end of discussion, this article calls on the reader to refer to the book of Hartono Ahmad Jaiz entitled Aliran dan Paham Sesat di Indonesia (Jakarta: Pustaka Al-Kautsar, 2002). 
MD (DDII) thinkers define the furü' aspects of Islam as those issues in which there is no dalil explaining them, or if there is, the meaning is not yet firm or is multivocal. They give the example of whether or not the ma'mum (followers) in saläh (prayer) are obliged to recite the Qur'anic chapter of al-fatihah (the exordium) following the imam (leader)'s recitation of the same chapter, based on the absence of a firm dalil. They argue that room for ijtihad is provided in matters such as this for Muslims who are academically qualified in the sense that they are "scholars who master Islamic knowledge". ${ }^{78}$ For them, this qualification requires an adherence to the literal account of the text. They insist that Muslims are deviant in these secondary aspects if they "innovate something which is unwarranted by the dakil, or which change the regulation in such a way that contradicts the existing dalil." ${ }^{\prime 9}$

Regarding the third category, maskìt 'anh aspects of Islam, MD (DDII) thinkers explain that these aspects are concerned with worldly matters which are not referred to explicitly by either the Qur'an or Hadith. In these matters, ijtibäd is allowed (mubāh/rewarded if correct, and not punished if wrong). ${ }^{80}$ This legal status of mubăh can, however, become haram if the result of ijtihäd contradicts the literal account of the existing dalil for the other matters. They go on to say that this change of legal status can happen "if one prohibits issues which are basically not prohibited." ${ }^{11}$ They even claim that this innovation is a deviation from Islam since it is the same as producing a new shari'ab. ${ }^{82}$ This indicates that the text is the measuring stick for MD (DDII) thinkers for judging the result of ijtibād. Also, this indicates that MD (DDII) thinkers brand as ḩaram any perceived deviation from Islamic teachings.

As a result, MD (DDII) thinkers appear very sensitive to any religious reinterpretation which might go beyond the literal accounts of Islamic texts. This sensitivity is particularly strong if the reinterpretation which contradicts the literal sense of Islamic texts refers to the primary aspects of Islam. It is in this context that they reject the

\footnotetext{
78 “Kesesatan Menggerogoti Ummat Islam", p. 35.

${ }^{79}$ See "Kesesatan Menggerogoti Ummat Islam”, p. 36.

80 “Kesesatan Menggerogoti Ummat Islam", p. 35.

${ }^{81}$ See "Kesesatan Menggerogoti Ummat Islam", p. 36.

82 “Kesesatan Menggerogoti Ummat Islam”, p. 36.
} 
idea of pluralism of religion as expressed by JIL thinkers which they argue can destroy the six pillars of iman, and is thus deviant from Islam. ${ }^{83}$

\section{Emphasising the Religio-ethical rather than the Literal Sense of the Text}

JIL thinkers, as partly indicated above, develop ijtihäd as an attempt to interpret Islam drawing on the religio-ethical sense of the Qur'an and the Sunnah rather than the literal meaning of them. This is parallel to their approach to Islamic textuality which focuses on universal moral values (maqāsid al-shari'ah), which are developed in the text, as also discussed above. This indicates that JIL thinkers perceive the essence of Islamic teachings as not identical with the verbatim utterances of the texts (or Revelation), but may go beyond them. Also, for them, the moral values of Islamic shari'ah exceed the capacity of the texts themselves. In the words of Abshar-Abdalla, "God [Islamic shari'ah] is All Greater than Text" (Allahu Akbar Minal Teks). ${ }^{84}$

For JIL thinkers, the need to interpret Islam from the religioethical perspective is due to the demand that Islam interact with human development. They argue, "Literal interpretation will only 'kill' Islam.," They further argue, "Only by an interpretation which is based on the spirit of religio-ethics, will Islam be able to survive and develop in creative ways so that it becomes part of universal 'human civilisation'." 86 Thus, for JIL thinkers, Islamic interpretation based on literal accounts of the texts may injure the principle of Islam as a universal religion which can be applied in any time and place because the texts are static, but human development is dynamic.

Based on their concept of finalised Revelation, as indicated above, MD (DDII) thinkers oppose any interpretation of Islam based on the religio-ethical spirit. As also mentioned above, it is clear that they even claim that those interpretations which go beyond literal accounts of texts are the same as rejecting the texts themselves.

This difference in approaching the text in Islamic interpretation indicates that the text occupies the central place for Muslims in

\footnotetext{
${ }^{83}$ See "Kesesatan Menggerogoti Ummat Islam", p. 35.

${ }^{84}$ Abshar-Abdalla, "Allahu Akbar (Minal 'Teks')", p. 58.

${ }^{85}$ See "Tentang Jaringan Islam Liberal".

86 “Tentang Jaringan Islam Liberal".
} 
understanding Islamic teachings. This is mainly because what has been bequeathed to them by Islam is the texts of Islam (as expressed in the Qur'an and Hadith as its main sources) and the commentaries of 'Ulama', on them as well as Muslim history, whereas the texts are themselves multi-interpretable. As a result, Muslims generally refer to the understanding of Islamic texts as the main basis for comprehending Islamic teachings, both with agreement and criticism, before analysing other resources, such as Muslim history.

\section{Identifying Truth as Relative, Open, and Plural}

In interpreting Islam, JIL thinkers believe in the principle that the 'truth' in religious interpretation is relative, open and plural. They identify religious interpretation as relative since it constitutes a human activity (kegiatan manusiawi) which is confined to a certain context. They argue that religious teachings are open for interpretation as every single interpretation contains two possibilities, being either true or false. They also regard religious interpretation as delivering a plural truth since it represents the pressing need of an interpreter in a certain time and place, which changes over time. ${ }^{87}$

MD (DDII) thinkers reject the concept of relative, open, and plural truth by JIL thinkers since for them, Islam recognises the concept of qat $i$ which indicates absolute truth. Syamsul Bahri Isma'iel, for example, argues that the relative and plural truth in religious interpretation has the same implication as emphasising human reason over Revelation. This is, according to Isma'iel, contradictory to the concept of qat $i$ which accepts human reasoning only if it does not destroy the literal accounts of the text. Based on this argument, Isma'iel accuses JIL thinkers of having neutralised the definite truth (kebenaran qath'iyat) with relativism, neglecting the principle of objectivism and absolutism. He further accuses liberal thinkers of regarding the absolute truth (al-haqq al-mutlaq) in religion as the same as a dream story, hallucination, illusion, or spirit of devil (roh halus). ${ }^{88}$

\footnotetext{
87 “Tentang Jaringan Islam Liberal”.

${ }^{88}$ Isma’iel, "Islam Liberal: Menafsirkan Agama", p. 25.
} 


\section{Sympathising with the Minority and the Oppressed}

Following their subscription to the principle of maqasid al-shari' ab, JIL thinkers focus on the notion of justice as the main criterion for their social actions. For them, Islam in principle does not devote itself to a certain group over the other. In reality, however, Muslims do not follow this principle as there are still social practices which favour powerful groups, and at the same time disadvantage the powerless. As a result, JIL thinkers argue for Islamic interpretation which is concerned with the small group (yang kecil), the minority, ${ }^{89}$ the oppressed (yang tertindas), and the marginalised (yang dipinggirkan). They define this "unfortunate group" in a wide range of issues, such as religion, ethnicity, race, culture, politics, economics, and sexual orientation. Furthermore, they insist that "every single socio-political structure which preserves the practices of injustice over the minority is against the spirit of Islam. ${ }^{, 90}$

Among the main issues concerning the minority and marginalised groups, JIL thinkers focus on the principle of gender equity (keadilan jender). They view gender equity as representing an important agenda since Muslims particularly in Indonesia still have an unfair social structure based on patriarchal ideas, which favour men over women. In their view, such inequality goes against the concept of justice in Islam: "We consider religious interpretations which are not concerned with the principle of gender equity as being against the Islamic principle of justice." ${ }^{\prime 91}$

As a concrete example of this principle of gender equity, JIL thinkers are particularly concerned with the national policy of regional autonomy (Basic Law on Regional Autonomy, No. 22/1999) under which religious and traditional leaders are able to attain greater power in society. Nasaruddin Umar, as a contributor to JIL, argues that in this context, women could become objects rather than subjects of actions due to the fact that the majority of local social structures support

\footnotetext{
${ }^{89}$ See "Tentang Jaringan Islam Liberal".

90 “Tentang Jaringan Islam Liberal".

${ }^{91}$ See "Tentang Jaringan Islam Liberal". See also an article by Nasaruddin Umar, a contributor to JIL, “Teologi Pembebasan Perempuan”, in Assyaukanie (ed.), Wajah Liberal Islam, pp. 44-5.
} 
the patrilineal system which favours man over woman. He urges therefore that Islam not be made use of as a tool of ideological power to favour one group over the other or a certain sex over the other. Instead he argues that Islam must be beneficial to all human beings. ${ }^{92}$

MD (DDII) thinkers appear to agree that Islam develops the principle of justice for all human beings. However, they differ from JIL thinkers in their perception of the principle of gender equity within male-female relationships. For MD (DDII) thinkers, man and woman are not equal in the sense that they are not supposed to always have the same portion in having significances in social, political, economic and religious matters. Despite this, they argue, the principle of justice does exist and is inherent in the non-equal relationship between man and woman. This is because, they specifically argue, if the Qur'an and Hadith have regulated this relationship suggesting that woman is concerned with domestic domain and man is with public domain, it is impossible that the explanation of the Qur'an and Hadith does not convey the principle of justice. ${ }^{93}$

As one example of the non-equal relationship between man and woman, MD (DDII) thinkers refer to the public office of president. They argue that "a female president is unjustified in Islamic law." They base their argument on a Hadith narrated by al-Bukhāri from Abi Bakrah containing a "recommendation" not to elect women as leaders, and commentaries of several 'ulamä' from both medieval Islam (such as Ibn Hazm, 994-1064 AD, who was known as a "literalist interpreter") and the contemporary era (such as Wahbah al-Zuhayli, a Syria-born scholar) who supported the prohibition of female president. They insist

${ }^{92}$ Umar, "Teologi Pembebasan Perempuan", p. 46.

${ }^{93}$ This is reflected, for example, in matters pertaining to inheritance. The distribution system of inheritance (1:2 for man and woman), for MD thinkers, should not be understood from the perspective of its percentage which not equal, but should be located in the frame of the obligation of the well-to-do family to help the unfortunate. See Fuad Amsyari, "Solusi Krisis Ekonomi dengan Syari'at Islam", Media Dakwah, no. 331 (January 2002), p. 32.

94 “Presiden Perempuan 'Batal' Menurut Hukum Islam", Media Dakwah, no. 356 (July 2004), p. 22. See also Dahlan Bashri At-Thahiry, "Wanita Dalam Kepemimpinan Negara: Penjelasan Hadits Abu Bakrah”, Media Dakwah, no. 356 July 2004), pp. 24-5. 
that a woman can only lead women, not the public where men and women share one domain, such as in the case of the presidency. ${ }^{95}$ This argument from MD (DDII) thinkers differs fundamentally from that of JIL thinkers, who say that woman can hold any position, both in private and public domains. ${ }^{96}$

Thus, we see the way in which JIL and MD (DDII) thinkers perceive the principle of justice. JIL thinkers do not rely on literal accounts of the texts. In contrast, MD (DDII) thinkers make restricted use of the texts. This again indicates that the debate between them is essentially based on their own approaches to textual interpretation.

\section{Freedom of Religion}

JIL thinkers argue that freedom of religion is basically an individual right, which deserves protection from public intervention. They further argue that any social prosecution based on religious ideas or faith cannot be tolerated or justified. ${ }^{97}$ This is because religion and faith for them represent a very personal domain. Abshar-Abdalla specifically argues that it is an "ethical assumption" (asumsi etis) that "human beings are free creatures, and their freedom must be protected by means of any kind." 98 Masdar F. Mas'udi, an active contributor to JIL, even maintains that public or state intervention in matters of religion is counter-productive since religion is based on personal consciousness (kesadaran), sincerity (keikhlasan), and devoutness (kekbusyukan). ${ }^{99}$

\section{Negara".}

95 “Presiden Perempuan 'Batal”'; At-Thahiry, "Wanita Dalam Kepemimpinan

${ }^{96}$ See also Qodir, Islam Liberal: Paradigma Baru, p. 185.

97 "Tentang Jaringan Islam Liberal”.

${ }^{98}$ Ulil Abshar-Abdalla, "'Over-Moralisasi' dalam Soal Inul: Tentang Tempat Agama dalam Ruang Publik", an epilogue for FX Rudy Gunawan, Mengebor Kemunafikan: Inul, Seks, dan Kekuasaan (Jakarta: Kawan Pustaka, 2003), p. 147.

${ }^{99}$ Masdar F. Mas'udi, “Keadilan Dulu, Baru Potong Tangan”, in Assyaukanie (ed.), Wajah Liberal Islam, 105. Mas'udi also argues that shari' ah is a moral and ethical concept which aims to promote human dignity (martabat manusia), and whose essence is justice. See his view in an interview with weekly magazine Gatra "Syariah Bukan Seperangkat Doktrin”, Gatra, no. 48, year IX (18 October 2003), p. 66. 
Based on this principle of freedom of religion, JIL thinkers have developed their ideas concerning the pluralism of religion. AbsharAbdalla, for example, maintains that all religions are the same, and Islam is not the only true religion. He insists that there is no exclusivism of religion in the sense that only one religion is true, and the others are wrong. ${ }^{100}$ Thus, for JIL thinkers, all religions are true and in parallel, representing various ways to come to the truth.

This argument on the equality of religions is based on JIL's understanding, as expressed by Abshar-Abdalla, of an important doctrine in Islamic aqidah which stresses the total awareness of continuity in two aspects: revelation (wahyu) and prophethood (kenabian). Islam, Abshar-Abdalla suggests, does not claim to be an innovation, but rather re-affirms and completes the message of the previous Prophets. ${ }^{101}$ It is upon this principle that Abshar-Abdalla perceives the equality of religions (Abrahamic or non-Abrahamic) as a religious reality which is also essentially supported by Islam.

MD (DDII) thinkers accuse JIL activists of straying substantially from the path of Islam. ${ }^{102}$ They argue that Islam has clearly differentiated itself from other religions. They point out that Islam stresses this differentiation based on the principle of Islamic shari'ab, as expressed by the nass qat i i of the Qur'an and the Sunnah. ${ }^{103}$ As a result, the idea of the pluralism of religion which considers all religions the same can be regarded as identical with rejecting the nașs (text) of the Qur'an and the Sunnah. ${ }^{104}$

MD (DDII) editors, by quoting the statements of their organic intellectual Jaiz, go so far as to accuse JIL thinkers of being heretical.

${ }^{100}$ This statement of Abshar-Abdalla is quoted by Gatra in one of its headlines. See "Tafsir Agama Pemicu Fatwa", Gatra, no. 05, year IX (21 December 2002), p. 29.

${ }^{101}$ Ulil Abshar Abdalla, "Kenabian Universal dan Kerentanan Bersama”, Gatra, no. 9, year IX (18 January 2003), p. 18.

102 “Menyamakan Semua Agama, Murtad", Media Dakwah, no. 342 (December 2002), p. 40.

103 “Bahaya Islam Liberal (3)”, 34-38; Akaha, “JIL, Potensi No! Ancaman Yes!”, p. 28.

104 "Menyamakan Semua Agama, Murtad”, 40; "Kewajiban Menerapkan Syari’at Islam, Membincang Kontroversi Islam Liberal”, Media Dakwah, no. 336 (June 2002), p. 40 . 
This is, in their opinion, because JIL thinkers consider non-Islamic religions as being the same as Islam, the true religion of God, whereas in fact, the MD editors claim, non-Islam religions are religions of the devil. ${ }^{105}$ The idea of pluralism of religion, as developed by JIL thinkers, causes confusion and a weakening of Islamic 'aqidah and shari' $a$ ah among Muslims. ${ }^{106}$ Based on their opposition to this idea, therefore, MD (DDII) thinkers accuse JIL activists of being apostates. ${ }^{107}$

\section{Separation between Mundane and Spiritual Authority, and between Religious and Political Authority}

JIL thinkers believe in the basic principle of the necessity of separation between religious and political authority. As a result, they support the idea of secularisation and separation between Islam and the state. They say, "The healthy state format for developing religion and politics is a state in which the two authorities [religion and politics] are separated." 108 However, they maintain that the recent debate about secularisation differs from that of the past, since the same debate about secularisation in the era of the New Order, as expressed by Madjid and Rasjidi, is finished. JIL thinkers, as represented by Abshar-Abdalla, develop the idea of secularisation based on the real challenges and needs of local areas across Indonesia. According to Abshar-Abdalla:

The debate about secularisation between Cak Nur [Nurcholish Madjid] and Rasjidi in the past decades is over. Because the problem now is much more real, such as how to respond to the implementation of Islamic shari'ah in Ciamis, which is detrimental to women due to the issuing of regulations for a night-time curfew for them. This real issue was absent from the thinking of Cak Nur or Rasjidi. This is because Cak Nur's idea of secularisation referred to the major philosophical works on secularisation. Thus, there was not a real-life issue. There was, of course, a real-life issue when Cak Nur discussed [Islamic] political parties, but this issue was different from the real problem we

105 “Islam Liberal Menolak Dialog Terbuka", Media Dakwah, no. 333 (March 2002), p. 56.

106 “Islam Liberal Menolak Dialog”, p. 56.

107 "Menyamakan Semua Agama”, p. 40.

${ }^{108}$ See "Tentang Jaringan Islam Liberal". 
are facing now, such as local authority-issued shari'ah regulations. Thus, [we] cannot deal with secularisation, using Turkey or Iran as references, but [we] have to refer to our own problem. ${ }^{109}$

JIL thinkers argue further that separation between Islam as a private domain and the state as a public domain must be well established in order to prevent disorder and disarray from happening as a result of confusion between the two domains. Abshar-Abdalla, for example, specifically argues for this separation while admitting at the same time that the demarcation line between the private and the public may be blurred, not clear-cut. The necessity of this separation, Abshar-Abdalla goes on to say, can be likened to the necessity of separation between "private money" (uang pribadi) and "office money" (uang kantor) which cannot be mixed up into one account. ${ }^{110}$ In spite of this necessity, he believes that "the more vital the private sphere as the field for maintaining and developing the '[political] vocation', the more important political actions in the public sphere will be."111

Moreover, Abshar-Abdalla regards the secular state as better, and more sophisticated, than the Islamic state. He argues that this is because the secular state can provide the opportunity for both the "potential for piety" (energi kesalehan) and the "potential for immorality" (energi kemaksiyatan) and allow them to interact to each other so that the former potential can actualise itself in a strong way through that interaction. On the other hand, Abshar-Abdalla notes, the Islamic state cannot do the same things since it does not facilitate the interaction between the potential for immorality and that for piety. ${ }^{112}$ As a result, Abshar-Abdalla insists, the capacity of the secular state is higher than that of the Islamic state.

${ }^{109}$ See Abshar-Abdalla's speech delivered in Seminar Discussion "Islam Liberal: Tantangan atau Ancaman?” organised by Indonesian Muslim Association-based Minaret, The Australian National University (ANU) Canberra, 14 July 2003.

${ }^{110}$ See Abshar-Abdalla' argument in: "Penayangan Maya Islam Liberal".

${ }^{111}$ Ulil Abshar-Abdalla, "Hidup Secara Ceriwis dan Sinis: Dilema antara Political Vocation dan Democratic Disenchantment (Sekadar Pertimbangan untuk Romo Benny)", an introduction to Benny Susetyo Pr, Orde Para Bandit (Yogyakarta: LKiS and Averroes Press, 2001), p. xxiv. 
It is in this context, therefore, that JIL thinkers oppose the idea of Islamic shari'ah implementation. Abshar-Abdalla believes that the implementation of shari'ah at the state level will narrow the Islamic point of view in such a way that Muslims' thinking may become confined to symbolic matters, such as wearing jilbäb (veil) and banning alcoholic drinks and adultery. ${ }^{113} \mathrm{JIL}$ 's contributor, Mas'udi, also argues that the implementation of shari'ah by the state will generate hypocrisy. He believes that in this context, the loyalty of Muslims to their religion depends largely on state intervention and coercion. ${ }^{114}$

Muslim Abdurrahman, another contributor to JIL, argues that the implementation of Islamic shari' $a$ h in Indonesia will give rise to disadvantages for several groups of society. These groups include women who will be marginalised due to there being regulations in Islam which restrict their movement, non-Muslim minorities who will become the second class citizen under this shari'ah-led state, and the poor who are more likely to be convicted of breaking the shari' $a$ h regulations than the well-to-do and the bureaucrats (such as in the case of corruption). ${ }^{115}$

112 “Islam Liberal versus Islam Literal”, Tempo, no. 38, year XXX (19 - 25 November 2001), 96. JIL later documented this report of Tempo, and re-published on its site. See Jaringan Islam Liberal website: http://www.islamlib.com/BERITA/ tempo.html (Accessed 17 December 2002).

113 “Tafsir Agama Pemicu Fatwa”, p. 29.

${ }^{114}$ See interview with Masdar F. Mas'udi, "Dibutuhkan Islam sebagai Spirit", Jaringan Islam Liberal website, 11 August 2002: http://www.islamlib.com/ WAWANCARA/masdar\%20spirit.html (Accessed 16 January 2003); idem., "Keadilan Dulu, Baru Potong Tangan", Jaringan Islam Liberal website, 22 July 2001: http:// www.islamlib.com/WAWANCARA/masdar.html (Accessed 16 January 2003). The latter article was later published as a part of a book. See Masdar F. Mas'udi, "Keadilan Dulu, Baru Potong Tangan", in Assyaukanie (ed.), Wajah Liberal Islam, 102-8. JIL also published a book on liberal thinkers' views of shari'ah. For more detail see Burhanuddin (ed.), Syariat Islam Pandangan Islam Liberal (Jakarta: Jaringan Islam Liberal and The Asia Foundation, 2003).

${ }^{115}$ See the interview of Muslim Abdurrahman with JIL: "Korban Pertama dari Penerapan Syariat adalah Perempuan”, Jaringan Islam Liberal website, 16 September 2001: http://www.islamlib.com/WAWANCARA/muslim.html (Accessed 16 January 2003). This interview report was later published as part of JIL's book. See Muslim Abdurrahman, "Korban Pertama Penerapan Syariat adalah Perempuan", in Assyaukanie (ed.), Wajah Liberal Islam, pp. 109-113. 
As a result, for JIL thinkers, religion must operate in the private sphere or personal domain. ${ }^{116}$ However, Abshar-Abdalla suggests, religion can certainly become the basis for public norms with two conditions. First, only universal (such as justice and equality), and not particular (such as amputating punishment), norms of religion can be brought into public domain. Second, religious norms must be initially processed through public debate in order to arrive at public consensus. ${ }^{117}$ Through this process of public deliberation, ${ }^{118}$ he points out, all elements of society can accept the public norms which are derived from religion.

The awareness that every religion has particular norms, and it cannot be brought therefore into public sphere directly, does not appear strong. Certainly, religion can become a source of public norms, with the condition that the [religious] norm has already been processed through public discussion in the public sphere, and its particular elements have been dropped. In other words, religion can become public norms after going through the process of "publicisation" [public deliberation]. ${ }^{119}$

116 “Tentang Jaringan Islam Liberal".

${ }^{117}$ See Abshar-Abdallah's view of relationship between religion and privatepublic domains in Abshar-Abdalla, "Over-Moralisasi' dalam Soal Inul”; Correspondence between Abshar-Abdalla and Nur Abdurrahman, "Wahyu itu Non-historis sekaligus Historis", 246-7 and 254. See also Ulil Abshar-Abdalla, Membakar Rumab Tuhan: Pergulatan Agama Privat dan Publik (Bandung: Remaja Rosdakarya, 1999).

${ }^{118}$ Public deliberation has a pivotal role to find out what Abshar-Abdalla calls 'public desire' (kehendak umum). He identifies public desire as unidentified (tidak berbentuke) and changing over times. It is in this context that public deliberation represents an important instrument to establish, and even to evaluate, public norms as the indications of public desire. For explanation of public desire, see Abshar-Abdalla, "Hidup Secara Ceriwis dan Sinis", p. xvii.

${ }^{119}$ See Abshar-Abdalla, “'Over-Moralisasi’ dalam Soal Inul”, p. 142. AbsharAbdalla relates religion to the authority of religion and reason. According to him, religion and reason must consider their own restrictions even though they are of the gravest importance in human life. In order to make a boundary of authority between religion and reason, therefore, he further argues that religion is especially concerned with private domain, just as reason is with public domain. If religion is willing to come to public domain, he goes on to say, it should bring only its "nilai-nilai besarannya" (universalmoral values), not its "tetek bengek" (particular-technical stipulations). He regards this formula as the best "treaty" between religion and continuously evolving human reason. See Ulil Abshar-Abdalla, "Goyangan Inul dan Rerasan Pribadi”, KMNU2000 Mailing List, 23 February 2003: kmnu2000@yahoogroups.com (Accessed 24 February 2003). 
MD (DDII) thinkers argue against JIL activists' views on the secular state, accusing them of having rejected the Islamic shari'ah itself by separating religion from state politics. ${ }^{120} \mathrm{MD}$ (DDII) thinkers also accuse Abshar-Abdalla and other JIL activists as preferring a sälih (pious) but fäsiq (godless/dishonest) figure to a salith and honest individual. Those ideas of the secular state, for MD (DDII) thinkers, contradict and violate the basic principle of Islamic proselytising (da'wab), amr bi'l-ma'rüf wa naby 'an'l-munkar, which is highly important in Islam since it calls on people to perform good deeds. This violation, MD (DDII) thinkers suggest, is based on JIL's blending of the evil and the good. ${ }^{121}$

MD (DDII) thinkers also oppose JIL thinkers' criticism of the implementation of Islamic shari'ah, based on both the history of Indonesia and the interpretation of religious texts. According to them, Indonesia as a nation state has not had any experience of the implementation of shari'ah where it is adhered to by the majority of Indonesian people. ${ }^{122}$ Thus it is impossible for JIL thinkers to reject shari'ah without knowledge of how it might work in Indonesia. As well, MD (DDII) thinkers refer to the Qur'anic verse (20:2), ${ }^{123}$ that Allāh (God) promised Islam always provides its followers with good things, ${ }^{124}$ and claim that JIL activists have ignored the meaning of this verse.

As regards the concept of public and private domains, MD (DDII) thinkers reject the idea of JIL thinkers that Islam assumes only a private domain of individuals which accepts no coercion from the public. They argue that Islam is not only as a private, but also as a public domain, an argument which was also developed by MD (DDII)

120 "Mahasiswa IAIN Jakarta Agar Bertaubat", Media Dakwah, no. 336 (June 2002), 10; "Jaringan Islam Liberal di Indonesia”, Media Dakwah, no. 333 (March 2002), p. 54.

121 "Landasan Keropos Islam Liberal", p. 20.

${ }^{122}$ Hartono Ahmad Jaiz, "Fenomena Menolak Syari'at", Media Dakwah, no. 335 (May 2002), p. 37.

${ }^{123}$ This verse reads: "Mà anzalnà 'alaykea al-Qur'än li tashqā [It was not to distress you that We revealed the Qur'ān]”. See the Qur'ann 20:2.

124 "Kewajiban Menerapkan Syari'at Islam", p. 40. 
thinkers in the New Order era. They base their argument on the concept of "total Islam" (Islam Kaffah), indicating that Islam regulates all aspects of life, not only private matters but also public. ${ }^{125}$ To be a Muslim, for them, means to practise Islam in all matters of life, and not to restrict it to the private domain. ${ }^{126}$

The debate between JIL and MD (DDII) thinkers concerning the concept of Islam in relation to private-public domain deserves analysis, especially from the perspective of social transformation. First, as indicated above, JIL thinkers discuss private issues in the public sphere. As a result, private issues are no longer private, but have become public concerns. Second, by perceiving of Islam as operating in the private sphere, JIL thinkers reject/ignore the possibilities for Islam to be a tool for social transformation. ${ }^{127}$ On the other hand, by perceiving of Islam as prevailing in private and public spheres, MD (DDII) thinkers are challenged by the fact that Indonesia is a heterogenous nation, especially in terms of religion and faith. As a result, the way in which Islam has to negotiate with other religions and faiths is not going to be smooth and easy if a compromise between them based on universal values is absent.

${ }^{125}$ This principle of total Islam by MD (DDII) is applied in all aspects, not only in the system of belief, but also in the system of social-politics and economy. For more detail of the total Islam by MD (DDII), see Taufiq Nugroho, Pasang Surut Hubungan Islam dan Negara Pancasila (Yogyakarta: Padma, 2003), p. 65.

${ }^{126}$ See "Dari Redaksi”, Media Dakwah, no. 349 (August 2003), p. 4. Jaiz, MD’s organic intellectual, takes an example of the Prophet Muhammad's attempt to almost burn the house of one of his companions due to his reluctance not to perform communal prayer (saläh bi al-jamā ah). He regards the fact that șalahb is a private domain, but the Prophet Muhammad still calls for performing it altogether with a strict sanction, as an indication that Islam is a private as well as a public domain. See Jaiz, "Fenomena Menolak Syari'at", p. 37. Sufandi Maruih, a contributor to MD, further accuses the campaign of JIL thinkers which regards Islam as only a private domain of being a result of Orientalism (he defines this term as the enemy of Islam) which seeks to make the religious understanding of Muslims shallow. See Sufandi Maruih, "Mewaspadai Orientalisme", Media Dakwah, no. 345 (March 2003), p. 30.

${ }^{127}$ See also Masdar F. Mas'udi, “Tanggung Jawab Publik Agama-agama”, Kompas, 7 February 2003. 


\section{E. Conclusion}

Over the previous thirty-two years, freedom to debate was extremely restricted by the Soeharto regime. All public discourses had to be delivered by, or at least be under strict supervision of, the state. In the New Order period, only ideas that supported the proliferation of capitalism and developmentalism, including the ideology of modernisation, and were not critical of the regime were acceptable to the state. ${ }^{128}$ The fact that the regime shut down several magazines, such as Tempo, Editor, and Detik, at the end of June 1994 is evidence of this state restriction. ${ }^{129}$

This state control of public debate has continuously decreased, however, since the collapse of the New Order regime. ${ }^{130}$ President Habibie, who replaced Soeharto, relaxed press controls. His successor, Abdurrahman Wahid, continued this relaxation. For the purposes of developing Islamic discourses in Indonesia, this relaxation paved an easier way for any Islamic thinking and intellectual bent to grow. JIL and MD (DDII) represent the miniature forms of two different intellectual bents in Islamic interpretation and understanding in pluralised Indonesian Muslims: liberalism and anti-liberalism.

This remark is not to suggest that there are only these two streams of Islamic thought within Indonesian Muslims. Indeed, Muslims in Indonesia are so plural that understanding the dynamic within them cannot be reduced to a dichotomy between liberal and anti-liberal

${ }^{128}$ See also Mansour Fakih, Jalan Lain: Manifesto Intelektual Organik (Yogyakarta: Pustaka Pelajar \& Insist Press, 2002), p. 132.

${ }^{129}$ A thoughtful analysis of Tempo in particular in the era of Soeharto's power can be found in Janet E. Steele, Wars Within: The Story of Tempo, An Independent Magazine in Soeharto's Indonesia (Jakarta: Equinox Pub.; Singapore: Institute of Southeast Asian Studies, 2005).

${ }^{130}$ This lessening of state control results from the fall of the top structure of the regime, that is, President Soeharto, which handled all state authorities. As illustrated by Liddle, the political pattern or structure of the New Order regime could be depicted as "a steeply-ascending pyramid" which was largely dominated by the authority of a single institution: President Soeharto. Thus, the figure of President Soeharto was so dominant in state life that every important policy was in the hands of him. See R. William Liddle, Leadership and Culture in Indonesian Politics (Sydney: Asian Studies Association of Australia and Allen \& Unwin, 1996), p. 18. 
Islamic movements. However, the Islamic movement of JIL illustrates attempts a certain group of Muslims makes to comprehend Islamic teachings by implementing liberalism in the context of modernisation in Indonesian Islam. By contrast, MD (DDII) represents an Islamic movement which is ideologically oriented to the promotion of conservatism and anti-liberalism within Indonesian Islam. MD (DDII) is highly concerned with the maintenance and purification of Islamic beliefs and understanding from the influence of other ideologies, including secularism and liberalism as widely developed in the West.

The current debates between JIL and MD (DDII) in the postSoeharto Indonesian Islam cannot be separated from the chains of intellectual base each of the two Islamic movements have. The intellectual agenda of each movement, referred to as a subject-matter, has been built on and influenced by its own methodological framework. The construction of its own methodological framework has resulted, however, from its own epistemological assumptions. As a result, attempts to comprehend Islamic movements in Indonesia cannot be undertaken thoroughly without some kinds of understanding of their intellectual base. The intellectual base appears to be deeply influential on the intellectual agenda of each movement. 


\section{BIBLIOGRAPHY}

Abdullah, M. Amien, "Arkoun dan Kritik Nalar Islami”, in Meuleman (ed.), Tradisi, Kemodernan dan Metamodernisme: Memperbincangkan Pemikiran Mohammed Arkoun, Yogyakarta: LKiS, 1996.

Abdurrahman, Muslim, "Korban Pertama dari Penerapan Syariat adalah Perempuan", Jaringan Islam Liberal website, 16 September 2001: http://www.islamlib.com/WAWANCARA/muslim.html (Accessed 16 January 2003).

Abshar Abdalla, Ulil, "Kenabian Universal dan Kerentanan Bersama", Gatra, no. 9, year IX (18 January 2003).

—, “'Over-Moralisasi' dalam Soal Inul: Tentang Tempat Agama dalam Ruang Publik", an epilogue for FX Rudy Gunawan, Mengebor Kemunafikan: Inul, Seks, dan Kekuasaan, Jakarta: Kawan Pustaka, 2003).

-, “Agama, Akal, dan Kebebasan: Tentang Makna 'Liberal' dalam Islam Liberal", Jawa Pos, 11 May 2003.

—, "Allahu Akbar (Minal 'Teks')", Tempo, No. 26, year XXXI (26 August - 01 September 2002).

-, "Apa Saya Harus Mengatakan Nabi itu Malaikat", Tabloid Warta (January 2003).

—, "Goyangan Inul dan Rerasan Pribadi", KMNU2000 Mailing List, 23 February 2003; kmnu2000@yahoogroups.com (Accessed 24 February 2003).

—, "Keragaman dalam Pandangan Islam", in M. Imdadun Rahmat, et al., Islam Pribumi: Mendialogkan Agama, Membaca Realitas, Jakarta: Erlangga, 2003.

—, "Membangunkan Kembali Islam", an introduction to Nur Khalik Ridwan, Islam Borjuis dan Islam Proletar: Konstruksi Baru Masyarakat Islam Indonesia, Yogyakarta: Galang Press, 2001.

—, "Menghindari Bibliolatri: Tentang Pentingnya Menyegarkan Kembali Pemahaman Islam", Jaringan Islam Liberal website, 8 February 2004; $\quad$ http://www.islamlib.com/id/ page.php?page $=$ article\&id $=251$ (Accessed 10 February 2003). 
—, "Menyegarkan Kembali Pemahaman Islam", Kompas, 18 November 2002.

—, "Re: Apakah “Yang Pribumi” Bisa Berbicara?_Buat Hamami (4)", Jaringan Islam Emansipatoris Mailing List, 7 October 2003; emansipatoris@yahoogroups.com (Accessed 7 October 2003)

—, "RE: Wawancara Afkar dgn Ulil Abshar-Abdalla", KMNU2000 Mailing List, 01 December 2003; kmnu2000@yahoogroups.com (Accessed 02 December 2003).

—, "Teks, Ortodoksi, Estetika: Sebuah Ketegangan”, in Aswab Mahasin et al. (eds.), Rub Islam dalam Budaya Bangsa: Konsep Estetika, Jakarta: Yayasan Festival Istiqlal, 1996.

—, "Wahyu Progresif”, in Luthfi Assyaukanie (ed.), Wajah Liberal Islam di Indonesia, Jakarta: Jaringan Islam Liberal and Teater Utan Kayu, 2002.

—, "Hidup Secara Ceriwis dan Sinis: Dilema antara Political Vocation dan Democratic Disenchantment (Sekadar Pertimbangan untuk Romo Benny)", an introduction to Benny Susetyo Pr, Orde Para Bandit, Yogyakarta: LKiS and Averroes Press, 2001.

-, Membakar Rumah Tuban: Pergulatan Agama Privat dan Publik Bandung: Remaja Rosdakarya, 1999.

Abshar-Abdalla, Ulil, et al., Islam Liberal dan Fundamental: Sebuah Pertarungan Wacana, $2^{\text {nd }}$ edition, Jogjakarta: eLSAQ Press, 2003.

Alief, Mohamad Ihsan, "Political Islam and Democracy: A Closer Look at the Liberal Muslims", Asia Program Special Report, no. 110 (April 2003).

Amsyari, Fuad, “Solusi Krisis Ekonomi dengan Syari'at Islam”, Media Dakwah, no. 331 (January 2002).

Arifin, Syamsul, "Liberalisme Islam Minus Epistemologi", in Islam Indonesia: Sinergi Membangun Civil Islam dalam Bingkai Keadaban Demokrasi (Malang: UMM Pres, 2003.

Bagir, Haidar, "Beberapa Pertanyaan untuk Ulil”, Kompas, 4 December 2002.

"Bahaya Islam Liberal (3): Lanjutan Edisi Februari 2002M", Media Dakwah, no. 333 (March 2002). 
Barton, Greg, Gagasan Islam Liberal di Indonesia: Pemikiran NeoModernisme Nurcholish Madjid, Djohan Effendi, Ahmad Wabib, dan Abdurrabman Wabid, 1968-1980, Jakarta: Pustaka AntaraParamadina, 1999

Burhanuddin (ed.), Syariat Islam Pandangan Islam Liberal, Jakarta: Jaringan Islam Liberal and The Asia Foundation, 2003.

Daud, Wan Mohd Nor Wan, "Tafsir Bukanlah Hermeneutika”, Media Dakwah, no. 348 (July 2003).

"Dialog Ulil Abshar-Abdalla - HM Nur Abdurrahman", posted by Dwi W. Soegardi on Jaringan Islam Liberal (JIL) Mailing List, 23 December 2002; islamliberal@yahoogroups.com (Accessed 23 December 2002).

"Disesalkan, Penghentian Sepihak Tayangan 'Islam Warna-Warni", Kompas, 14 August 2002.

Fakih, Mansour, Jalan Lain: Manifesto Intelektual Organik, Yogyakarta: Pustaka Pelajar \& Insist Press, 2002.

Greco, John, "Introduction: What is Epistemology", in John Greco and Ernest Sosa (eds.), The Blackwell Guide to Epistemology, Oxford, UK: Blackwell Publishers Inc., 2001.

Greg Barton, "The Emergence of Neo-Modernism; A Progressive, Liberal, Movement of Islamic Thought in Indonesia: A Textual Study Examining the Writings of Nurcholish Madjid, Djohan Effendi, Ahmad Wahib and Abdurrahman Wahid 1968-1980", Unpublished Dissertation, Monash University, Victoria, Australia, 1995.

Hamid Basyaib, "Islib Butuh Metodologi?: Tanggapan untuk Haidar Bagir", Republika, 23 March 2002.

Harjanto, Nicolaus Teguh Budi, "Islam and Liberalism in Contemporary Indonesia: The Political Ideas of Jaringan Islam Liberal (The Liberal Islam Network)", (Unpublished MA Thesis, College of Arts and Sciences, Ohio University, Athens, 2003).

“Hermeneutika, Tafsir al-Qur'an, dan Tokoh Muhammadiyah", Media Dakwah, no. 348 (July 2003).

Hidayat, Komaruddin, "Arkoun dan Tradisi Hermeneutika", in Johan Hendrik Meuleman (ed.), Tradisi, Kemodernan dan Metamodernisme: 
Memperbincangkan Pemikiran Mohammed Arkoun, Yogyakarta: LKiS, 1996.

Husaini, Adian and Nuim Hidayat, Islam Liberal: Sejarah, Konsepsi, Penyimpangan, dan Jawabannya, Jakarta: Gema Insani Press, 2002.

Husaini, Adian, "Liberalisasi Islam di Indonesia: Dekonstruksi, Belum Rekonstruksi", Aula (January 2003).

"Impor", Media Dakwah, no. 348 (June 2003)

"Islam Liberal dan Misinya", Media Dakwah, no. 332 (February 2002).

"Islam Liberal Menolak Dialog Terbuka", Media Dakwah, no. 333 (March 2002).

"Islam Liberal versus Islam Literal", Tempo, no. 38, year XXX (19 - 25 November 2001).

“Islam Warna-Warni”, Jaringan Islam Liberal Website, 11 August 2002; http://www.islamlib.com/id/page.php?page $=$ article\&id $=236$ (Accessed 10 October 2003).

Isma’iel, Syamsul Bahri, "Islam Liberal: Menafsirkan Agama dengan Hermeneutika Barat", Media Dakwah, no. 334 (April 2002).

Jaiz, Hartono Ahmad, "Fenomena Menolak Syari'at", Media Dakwah, no. 335 (May 2002).

- Aliran dan Paham Sesat di Indonesia, Jakarta: Pustaka Al-Kautsar, 2002.

—, Bahaya Islam Liberal, Jakarta: Pustaka Al-Kautsar, 2002.

"Jejak Kristen dalam Islamic Studies", Media Dakwah, no. 347 (June 2003).

“Kesesatan Menggerogoti Ummat Islam”, Media Dakwah, no. 347 (May 2003).

"Kewajiban Menerapkan Syari'at Islam, Membincang Kontroversi Islam Liberal", Media Dakwah, no. 336 (June 2002).

Liddle, R. William, Leadership and Culture in Indonesian Politics, Sydney: Asian Studies Association of Australia and Allen \& Unwin, 1996. "Manifesto Jaringan Islam Liberal", Gatra, no. 2-3, year X (6 December 2003). 
Martin, Richard C., et al., Defenders of Reason in Islam: Mu'tazilism from Medieval School to Modern Symbol, Oxford, England: Oneworld Publications, 2003.

Maruih, Sufandi, "Mewaspadai Orientalisme", Media Dakwah, no. 345 (March 2003).

Mas’udi, Masdar F., "Keadilan Dulu, Baru Potong Tangan”, in Luthfi Assyaukanie (ed.), Wajah Liberal Islam di Indonesia, Jakarta: Jaringan Islam Liberal and Teater Utan Kayu, 2002.

-, "Dibutuhkan Islam sebagai Spirit", Jaringan Islam Liberal website, 11 August 2002; http://www.islamlib.com/WAWANCARA/ masdar\%20spirit.html (Accessed 16 January 2003)

—, "Syariah Bukan Seperangkat Doktrin", Gatra, no. 48, year IX (18 October 2003).

—, "Tanggung Jawab Publik Agama-agama”, Kompas, 7 February 2003. Media Dakwah, no. 332 (February 2002).

Media Dakwah, no. 333 (March 2002).

"Menyamakan Semua Agama, Murtad", Media Dakwah, no. 342 (December 2002).

Mohammed Arkoun, Al-Islām: Al-Akblāq wa al-Siyāsah, transl. by Hashìm Șălị̣, Beirut: Markaz al-Inmā’ al-Qawmī, 1990.

Muzakki, Akh., "Otentisitas, Problem Dasar Islam”, Media Indonesia, 2 May 2003.

Noor, Farish A., 'The Challenges and Prospects for 'Progressive Islam' in Southeast Asia: Reclaiming the Faith in the Age of George Bush and Osma ben Laden", (Paper presented for the Centre for Modern Orient Studies, Berlin, 2004).

Nugroho, Taufiq, Pasang Surut Hubungan Islam dan Negara Pancasila, Yogyakarta: Padma, 2003.

"Oleh2 dari Australia", Jaringan Islam Liberal Mailing List, 22 July 2003; islamliberal@yahoogroups.com (Accessed 23 July 2003)

"Oleh2 dari Australia (2)", Jaringan Islam Liberal Mailing List, 22 July 2003; islamliberal@yahoogroups.com (Accessed 23 July 2003). 
Panggabean, Samsu Rizal, "Prospek Islam Liberal di Indonesia", in Luthfi Assyaukanie (ed.), Wajah Liberal Islam di Indonesia, Jakarta: Jaringan Islam Liberal and Teater Utan Kayu, 2002.

"Penguasa Muslim Tak Jamin Islami”, Media Dakwah, no. 338 (August 2002).

"Pengusung Adat dan Aliran Sesat: Musuh Utama Syari'at", Media Dakwah, no. 338.

“Presiden Perempuan 'Batal' Menurut Hukum Islam”, Media Dakwah, no. 356 (July 2004).

"Program Jaringan Islam Liberal", Jaringan Islam Liberal website: http:/ Lwww.islamlib.com/REDAKSI/jaringan.html (Accessed 21 December 2002)

Qodir, Zuly, Islam Liberal: Paradigma Baru Wacana dan Aksi Islam Indonesia (Yogyakarta: Pustaka Pelajar, 2003), p. 183.

"Re: Berpikir Obyektif", Jaringan Islam Liberal Mailing List, 28 July 2003; islamliberal@yahoogroups.com (Accessed 29 July 2003)

"Re: Curhat Saya: Masih Soal Aswaja", KMNU2000 Mailing List, 26 May 2003; kmnu2000@yahoogroups.com (Accessed 27 May 2003) Rucita, Ceceng, "JIL dan Logika Iblis", Media Dakwah, no. 336 (June 2002).

Sahal, Ahmad, "Umar bin Khattab dan Islam Liberal", in Luthfi Assyaukanie (ed.), Wajah Liberal Islam di Indonesia, Jakarta: Jaringan Islam Liberal and Teater Utan Kayu, 2002.

Shihab, Quraish, “Mengapa Tidak Mengikuti Kesepakatan OKI?”, Jawa Pos, 8 December 2002.

Steele, Janet E., Wars Within: The Story of Tempo, An Independent Magazine in Soeharto's Indonesia, Jakarta: Equinox Pub.; Singapore: Institute of Southeast Asian Studies, 2005.

"Tafsir Agama Pemicu Fatwa", Gatra, no. 05, year IX (21 December 2002).

"Tafsir Liberal dari Utan Kayu", Gatra, no. 3, year VIII (8 December 2001).

Tempo, no. 5, year XXXI (7 April 2002). 
Akh. Muzakki

"Tentang Jaringan Islam Liberal", Jaringan Islam Liberal website: http:/ Lwww.islamlib.com/REDAKSI/tentang.html (Accessed 21 December 2002).

At-Thahiry, Dahlan Bashri, "Wanita Dalam Kepemimpinan Negara: Penjelasan Hadits Abu Bakrah”, Media Dakwah, no. 356 (July 2004).

The Oxford English Dictionary, vol. X, Su-Sz, Oxford: Oxford University Press, 1978.

“Tokoh JIL Disuruh Tobat”, Media Dakwah, no. 342 (December 2002).

Zada, Khamami, Islam Radikal: Pergulatan Ormas-ormas Islam Garis Keras di Indonesia, Jakarta: Teraju, 2002. 